\title{
Results of the Separations
}

\section{Area Ground-Water Monitoring Network for 1980}

\author{
M.J. Graham \\ W.R. Brown
}

Prepared for the United States

Department of Energy

Under Contract DE-AC06-77RL01030

Rockwell International

Rockwell Hanford Operations

Energy Systems Group

Richland, WA 99352 


\section{DISCLAIMER}

This report was prepared as an account of work sponsored by an agency of the United States Government. Neither the United States Government nor any agency Thereof, nor any of their employees, makes any warranty, express or implied, or assumes any legal liability or responsibility for the accuracy, completeness, or usefulness of any information, apparatus, product, or process disclosed, or represents that its use would not infringe privately owned rights. Reference herein to any specific commercial product, process, or service by trade name, trademark, manufacturer, or otherwise does not necessarily constitute or imply its endorsement, recommendation, or favoring by the United States Government or any agency thereof. The views and opinions of authors expressed herein do not necessarily state or reflect those of the United States Government or any agency thereof. 


\section{DISCLAIMER}

Portions of this document may be illegible in electronic image products. Images are produced from the best available original document. 


\title{
Q
}

\section{Rockwell International}

\author{
Rockwell Hanford Operations \\ Energy Systems Group \\ Richland, WA 99352
}

PRELIMINARY REPORT

This report contains information of a preliminary nature. It is subject to revision or correction and therefore does not represent a final report. It was prepared primarily for internal use within Rockwell Hanford Operations. Any expressed views and opinions are those of the author and not necessarily of the Company.

\section{DISCLAIMER}

This report was prepared as an account of work sponsored by an agency of the United States Government. Neither the United States Government nor any agency thereof, nor any of their employees, makes any warranty, express or implied, or assumes any legal liability or responsibility for the accuracy, completeness, or usefulness of any information, apparatus, product, or process disclosed, or represents that its use would not infringe privately owned rights. Reference herein to any specific commercial product, process, or service by trade name, trademark, manufacturer, or otherwise, does not necessarily constitute or imply its endorsement, recommendation, or favoring by the United States Government or any agency thereof. The views ¿nd opinions of authors expressed herein do not necessarily state or reflect those of the United Stites Government or any agency thereof. 


$$
\text { RHO-LD--165 }
$$

DE82.006951

\title{
RESULTS OF THE SEPARATIONS AREA GROUND-WATER

\author{
MONITORING NETWORK FOR 1980 \\ RESULTS OF THE SEPARATIONS AREA GROUND-WATER
}

RHO-LD-165

Informal Report

\author{
M. J. Graham \\ W. R. Brown
Environmental Technologies Group
Environmental Analys is and Monitoring Department
Heal th, Safety and Environment Function

November 1981

Prepared for the United States

Department of Energy under

Contract OE-ACO6-77RL01030 
THIS PAGE

WAS INTENTIONALLY

LEFT BLANK 

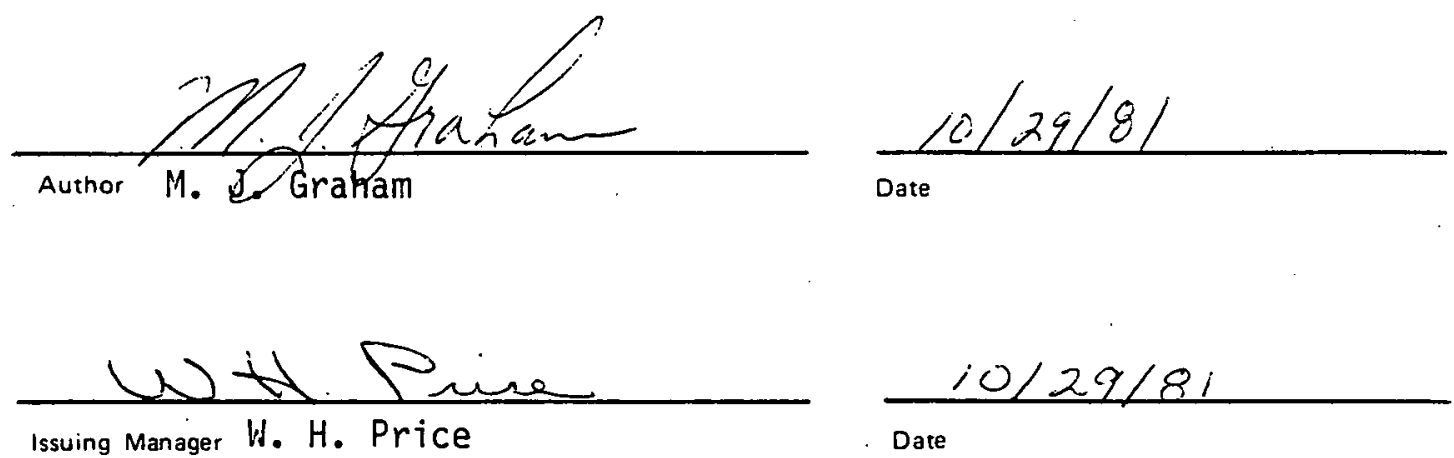

$\frac{10 / 29 / 81}{\text { Date }}$
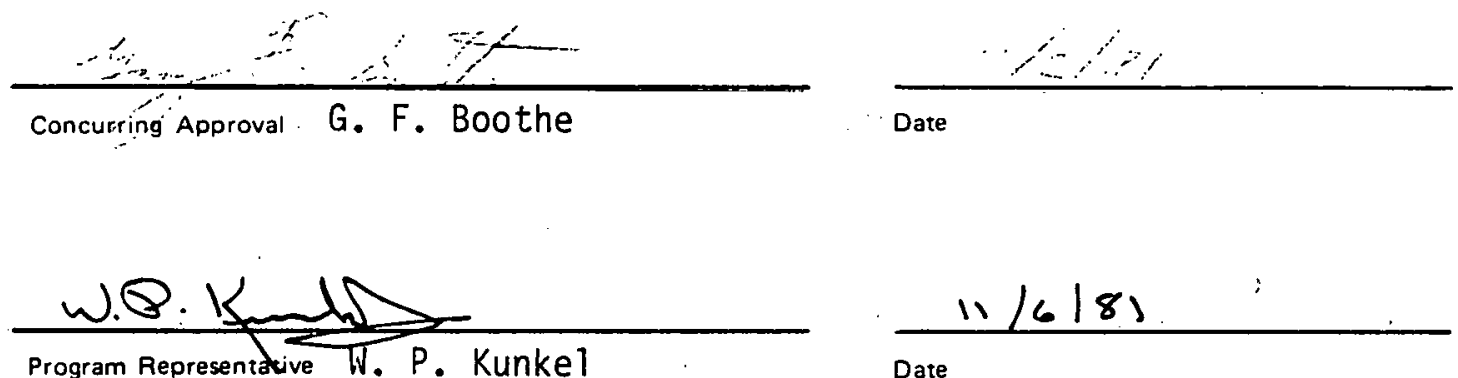

$\frac{11 / 6 / 81}{\text { Date }}$
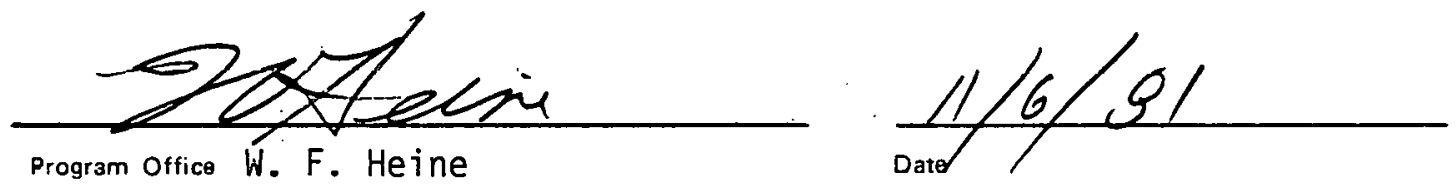

\section{Rockwell International}

Rockwell Hanford Operations Energy Systems Group 


\section{THIS PAGE}

\section{WAS INTENTIONALLY}

LEFT BLANK 


\section{CONTENTS}

Introduction . . . . . . . . . . . . . .

Background ..................... I

Purpose and Objectives ................ 1

Hydrogeology .................... 3

Separations Area Ground-Water Monitoring Program . . . . . . 7

Well Network . . . . . . . . . . . . . . . . 7

Sampling .................. . . 10

Water-Level Measurements . . . . . . . . . . . . 10

Analyses ....................... . . 11

Data Intepretation, Reporting, and Storage ....... 11

Qual ity Assurance ............... 12

Results From 1980 ................. . . 13

Site-Specific Results . . . . . . . . . . . . . 13

Contamination Plumes .............. 21

Summary ................... 31

Bibliography ................... 33

Appendices:

A. Rockwell Ground-Water Monitoring Schedule for the

Separations Area . . . . . . . . . . . A-1

B. Water-Level Monitoring Well Networks . . . . . . . B B-1

C. Water-Level Measurement Data for 1980 . . . . . . . C-1

D. Rockwell Ground-Water Monitoring Network -

FIGURES:

1. Separations Area Location Map . .......... . 2

2. Separations Area Water-Table Map 1980 . . . . . . . . 5

3. Diagram of We11 299-W18-15 Construction . . . . . . 8

4. Diagram of Well 299-E28-23 Construction . . . . . . 9 9

5. Well 299-W23-9 Tritium Concentration History Graph . . 15

6. We11 299-W23-10 Trit1um Concentration Hislury

Graph . . . . . . . . . . . . . 16

7. Tritium Concentration in Discharge to Crib 216-5-25 and Well 299-W23-10 ............. 17

8. We11 299-W19-3 90Sr Concentration History Graph . . . . 19

9. We11 299-W22-1 90 Sr Concentration History Graph ... . 20

10. Well 299-W15-4 Nitrate Concentration History Graph . . . 22

11. Gross Beta Plume Map - Separations Area . . . . . . . . 23

12. Nitrate Plume Map - Separations Area . . . . . . . . . 25

13. Tritium Plume Map - Separations Area . . . . . . . . . 27 
RHO-LD-143

TABLES:

1. Active Disposal Sites, 1980 ............. 14

2. Wells Yielding Samples Exceeding $45 \mathrm{mg} / \mathrm{L}$ Nitrate... . 21

PLATE;

1. Hanford Site Water Table Map, December 1980 . . . . (in packet) 
RHO-L:D-165

INTRODUCT ION

BACKGROUND

The U.S. Department of Energy (DOE) Hanford Site has served as an integrated nuclear facility since 1943. Rockwell Hanford Operations (Rockwell) is a prime contractor to DOE at the Hanford Site. Rockwell operates and maintains the irradiated uranium fuels processing facilities, plutonium separation facilities, and the major waste storage and disposal facilities which are located within the Separations Area (Figure 1).

As part of the waste management effort, a comprehensive unconfined ground-water monitoring network is established for the Separations Area (Graham, 1981). The Separations Area ground-water monitoring program satisfies DOE requirements that all onsite discharges be monitored. These requirements are stated in DOE Orders 5484.1 and 5480.1 , Chapters XI and XII.

In addition to the Separations Area ground-water monitoring program, Pacific Northwest Laboratory (PNL) maintains the Hanford ground-water monitoring program. The purpose of the Hanford ground-water monitoring program is to estimate and evaluate the impact of unconfined groundwater contamination from the Hanford Site on the general public. Groundwater sampling and analyses for the two programs are coordinated and data are actively exchanged.

PURPOSE AND OBJECTIVES

The purpose of this report is to summarize and interpret the results of the Separations Area ground-water monitoring program for calendar year 1980.

The objectives of this monitoring program are:

- To establish and maintain an observation well network for monitoring water quality in compliance with DOE Orders and other applicable state and federal regulations 


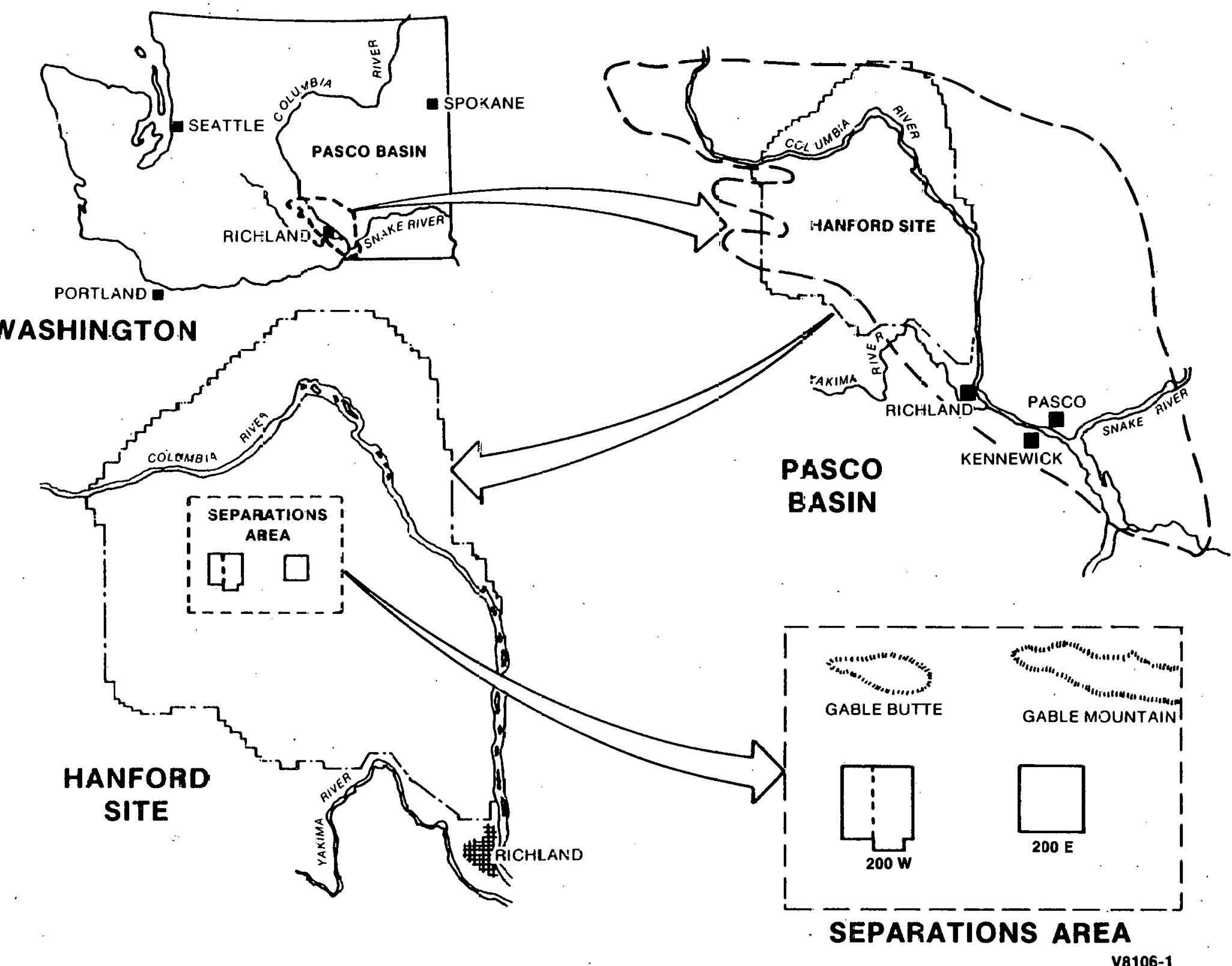

FIGURE 1. Separations Area Location Map. 
- To obtain representative radiological and chemical waterquality data near liquid waste disposal facilities in order to (1) assess the performance of these disposal sites; (2) determine the impact of liquid waste discharges on the quality of ground water; and (3) provide data for input to ground-water flow and transport predictive models

- To produce water-table maps to aid in determining the impact of discharges on the ground-water flow rates and directions of flow on the Hanford Site.

HYDROGEOLOGY

\section{Occurrence}

The unconfined aquifer is contained within the Ringold Formation, a Pliocene fluvial sedimentary unit with some lacustrine sediments, and the glaciofluvial sediments informally named the Hanford formation. The Ringold Formation is divided into four major textural units: the basal, lower, middie, and upper units (Taliman et al., 1979). Beneath the unconfined aquifer is a confined aquifer system consisting of sedimentary interbeds and/or interflow zones which occur between dense basalt flows or flow units. The bottom of the unconfined aquifer is the basalt surface or, in some areas, a clay zone in the Ringold Formation.

\section{Aquifer Properties}

Large differences in aquifer properties are evident between the Hanford formation and the middle member of the Ringold Formation, the major geologic units of the unconfined aquifer. Hydraulic conductivities range from 3 to 3,000 meters/day ( 9 to 30,000 feet/day); storage ropefficients range from 0.02 to 0.07 . The lower values are associated with the middle Ringold Formation; the higher values with the Hanford formation. There is a general increase in transmissivity from 200 west Area to 200 East Area. This is attributed to an increase in the saturated thickness caused by a drop in the surface of the basalt and the 
extension of the unconfined aquifer into the more permeable glaciofluvial sediments. The aquifer is anisotropic, with horizontal to vertical hydraulic conductivity ratios of 13 to 16 . The basal. unit acts as a separate confined aquifer system in some areas.

\section{Flow Dynamics}

Artificial recharge to the Separations Area from liquid waste disposal is estimated at 10 times the natural recharge (Graham et al., 1981). This artificial recharge has created two ground-water mounds (Figure 2) under 216-U-10 and 216-B-3 Ponds (U-Pond and B-Pond). Flow lines re drawn perpendicular to the water-tabie contour, equipulential lines which indicate the direction of flow. Flow is predominantly west to east. Discharge out of the Separations Area is primarily southeast to the Columbia River. There is also discharge to the east and north between Gable Mountain and Gable Butte. 


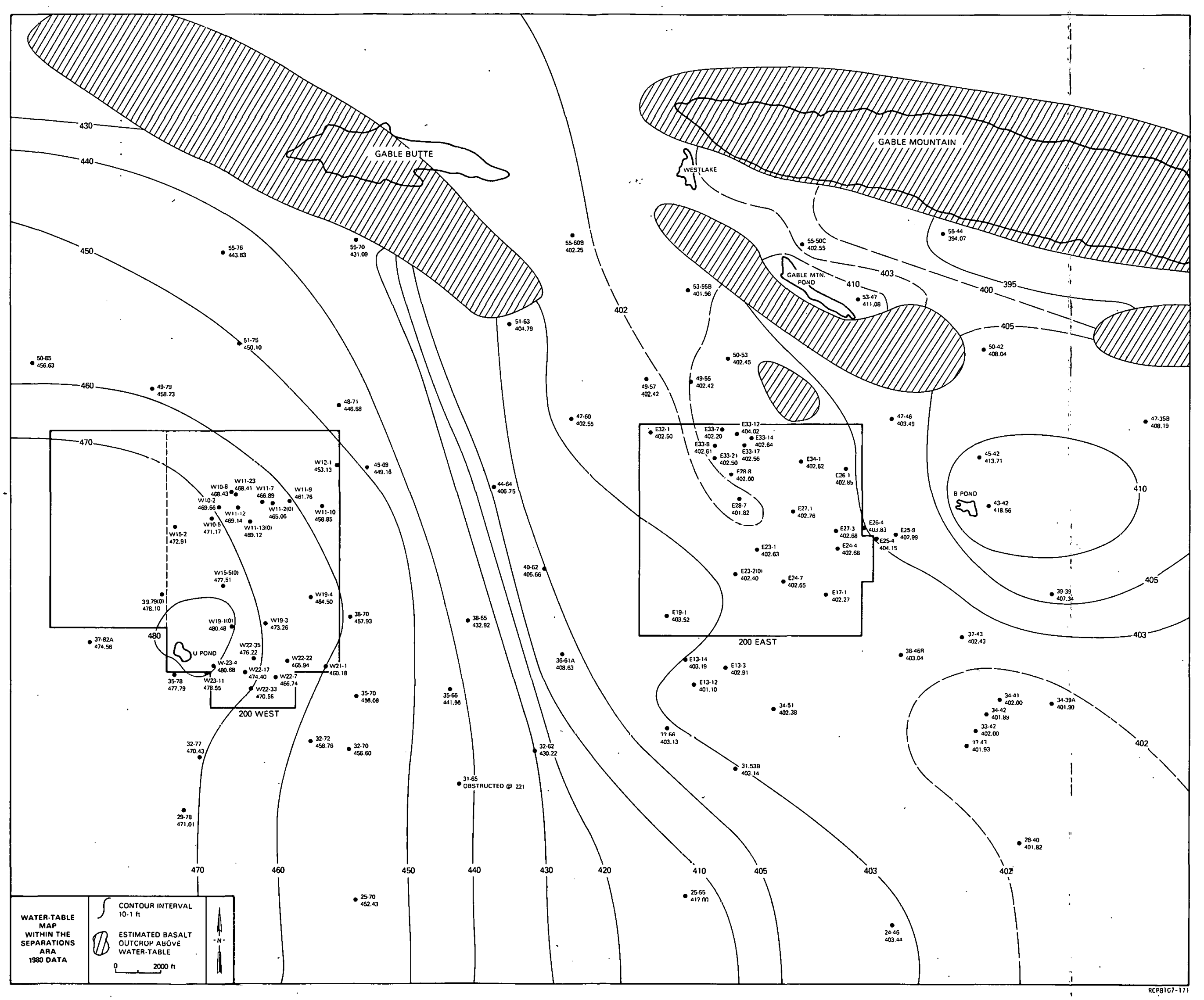

RH0-LD-165 
The monitoring program for assessing ground-water quality under low-level radioactive disposal facilities is based upon an understanding of the hydrology of this area. knowledge of the ground-water flow system predicates well location, well completion, and sampling frequency.

\section{WELL NETWORK}

There are 107 water quality monitoring wells in the Separations Area ground-water monitoring network (Appendix A). The wells are predominantly 15 centimeters ( 6 inches) or 20 centimeters ( 8 inches) in diameter. Each well is being fitted with a 1/2-horsepower submersible pump. Most wells are completed in the upper portion of the aquifer; the distribution of contamination with depth is being investigated.

Two new monitoring wells were drilled in 1980 and are scheduled to be added to the network in 1981. Wel1 299-W18-15 (Figure 3) monitors the active U-Pond. We17 299-E28-23 (Figure 4) monitors the inactive 216-B-5 Reverse We11, and includes a gravel pack to retain the fine silts prevalent in the sediments of that area.

Ten existing wells were also added to the network in 1980 . Wells 299-E25-17, -18, -19, and -20 monitor the active 216-A-37 Crib. We11 299-E28-13 monitors the active 216-B-55 Crib; Well 299-E34-1 monitors the active 215-B-63 Ditch. Four 600 Area wells formerly designated as PNL monituriny structures are now part of the Rockwell network. These wells and the active sites monitored by each well are as follows:

- 699-32-72 (216-S-19 Pond)

- 699-35-78 (U Pond)

- 699-53-47 (216-A-25 Pond)

- 699-53-55A (216-A-25 Pond). 


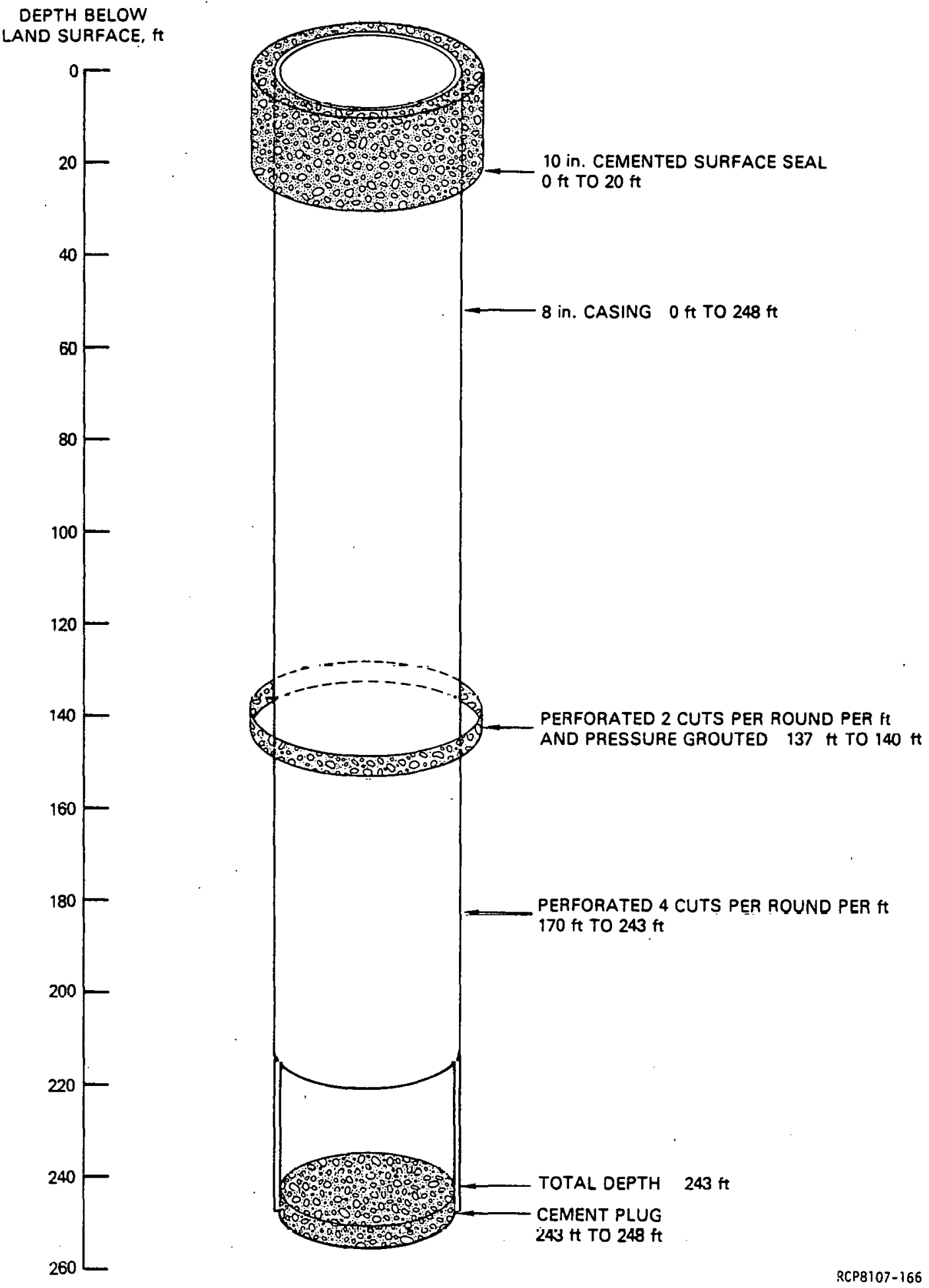

FIGURE 3. Diagram of Well 299-W18-15 Construction. 


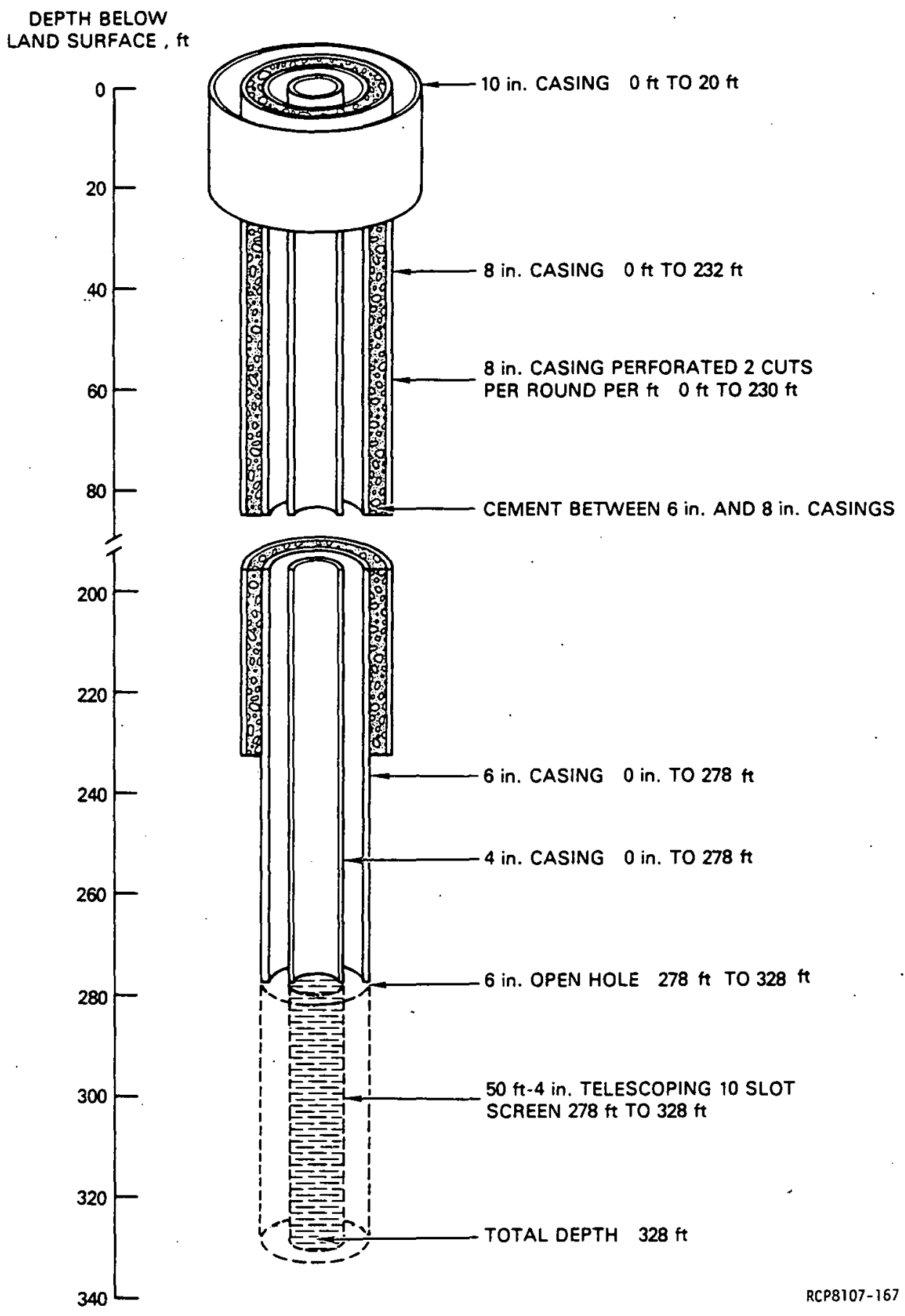

FIGURE 4. Diagram of Well 299-E28-23 Construction. 
SAMPLING

The following criteria are established for determining sampling frequencies.

- Wells monitoring active liquid waste disposal sites are sampled monthly.

- Wells monitoring inactive liquid waste disposal sites which contain contaminants that have a high potential of being remobilized are sampled monthly.

- Wells monitoring inactive liquid waste disposal sites which contain greater than 1 kilogram of transuranic wastes are sampled monthîy.

- Wells (other than specified sites mentioned above) indicating contamination above background concentration levels are sampled bimonthly or quarterly depending upon the level of contamination and the stability of the concentration trend.

- Wells yielding samples indicating background contamination are sampled semiannually.

Standard field procedures are used to collect the ground-water samples. The samples are field prepared for subsequent analyses.

\section{WATER-LEVEL MEASUREMENTS}

The water-table elevation monitoring network and the confined aquifer water-jevei monitoring network are given in Appendix B. Data for the piezometer network are also given in Appendix B. All waterlevel measurements are taken to the nearest 0.01 foot with a steel tape. A map depicting water-level elevations is produced annually for the Hanford Site (in packet). Water-table maps and depth to water-table maps are produced semiannually for 200 East and 200 West Areas. In addition, a water-table map for the Separations Area is produced for this report (see Figure 2 ). 


\section{ANALYSES}

The analytical schedules (see Appendix A) are based upon the inventory of the sites being monitored and the concentration histories of the wells. The samples are selectively analyzed for the following radionuclides: total alpha, total beta, ${ }^{60} \mathrm{Co},{ }^{106} \mathrm{Ru},{ }^{137} \mathrm{Cs},{ }^{90} \mathrm{Sr}$, tritium, and uranium. Nitrate is also present in the process waste streams and is used routinely at Hanford to define contamination in the ground water. The analyses are performed by United States Testing Company and given in Procedural Manual UST-RL-PM-9-80.

DATA INTERPRETATION, REPORTING, AND STORAGE

Data are interpreted in a timely manner, usually the same day the results are obtained from the laboratory. The data are interpreted to assess the performance of the active liquid waste disposal facilities and to determine general contamination patterns. In assessing the performance of the disposal sites, the data are compared with the DOE concentration guides for water in an uncontrolled area. If the groundwater contamination from an active site exceeds $10 \%$ of the concentration guidelines given in Table II (see DOE Order 5480.1, Chapter XI) for the long-lived radionuclides (with the exception of tritium*), the disposal facility is removed from service. This standard of $10 \%$ is adopted to assure that the concentration guides are not exceeded by subsequent drainage after shutoff.

Contamination plumes are used to indicate general patterns of ground-water contamination, which is primarily the result of past disposal practices. Contamination plumes for the Hanford Site are given in Eddy and Wilbur (1981). Analysis of data from the ground-water monitoring network indicates that contamination levels in ground water migrating out of the Separations Area are below DOE concentration guidelines for water in an uncontrolled area.

\footnotetext{
*Tritium concentrations are allowed to reach Table II guidelines in the ground water because no further increase in concentration is expected after shutoff.
} 
The data from the Separations Area ground-water monitoring network are stored on the Comprehensive Information Retrieval and Model Input Sequence (CIRMIS) computer data-base system. In addition to this annual report, quarterly reports are also issued. A summary of this report will be included in the annual environmental surveillance report for the Separations Area.

\section{QUALITY ASSURANCE}

Quality Assurance is an integral-part of the Separations Area ground-water monitoring program. The quality assurance program consists of internal and external audits. For each aspect of the routine program, and every party involved in the program, internal audits are performed annualiy, as a series of independent audits or a single comprehensive audit. These audits address the following items:

- Documentation of well condition and maintenance

- Compliance with sampling and analytical procedures

- Precision and accuracy of analytical resuits

- Evidence of data review, interpretation, and response

- Evidence of internal audit rejports.

The external audits, which are performed by the Rockwell Quality Assurance Function, address compliance with internal quality assurance programs. 
Water-level measurements are given in Appendix $C$ for wells in the unconfined aquifer. Water-quality data are given in Appendix $D$.

\section{SITE-SPECIFIC RESULTS}

\section{Active Liquid-Waste Disposal Sites}

There were seven active cribs, and four active ponds and associated active ditches in 1980 (Table 1). The 216-A-3 Crib and the 216-S-11 Ditch are not monitored because they receive minor discharges.

In 1980, concentrations of radionuclides (except tritium) in samples from the wells monitoring these active sites were below $10 \%$ of Table II guidelines. Tritium, in samples from wells monitoring 216-A-37 Crib, reached $33 \%$ of Table II guidelines and samples from a well monitoring 216-S-25 Crib exceeded Table II guidelines.

The 216-A-37 Crib received discharges of 242-A Evaporator steam condensate containing tritium in concentrations as high as $4,390 \mathrm{pCi} / \mathrm{mL}$ in 1980 ( 1.6 times Table II guidelines). Discharge of process condensate from the 242-S Evaporator to 216-5-25 Crib contained tritium concentrations as high as $3,930 \mathrm{pCi} / \mathrm{mL}$. Tritium is incorporated into water molecules and is not adsorbed onto the sediments. Therefore, the tritium discharged to a crib will move under unsaturated flow to the ground water. The other long-lived radionuclides prevalent in the waste stream are strongly adsorbed (Routson et al., 1979) and thus do not reach the ground water readily. 
TABLE 1. Active Disposal Sites, 1980.

PONDS AND DITCHES

216-A-25 Gable Mountain Pond and Ditches

216-B-3 B-Pond and Ditches

216-B-63 B-Plant Trench

216-S-11 Redox Chemical Sewer Ditch

216-S-19 222-S Laboratory Pond

216-U-10 U-Pond and Ditches

CRIBS ANU SPECIFIC RETENTIUN

216-A-3 203-A Silica Gel Wastes

216-A-30 Purex Steam Condensate

216-A-37 242-A Process Condensate

216-B-55 B-Plant Steam Condensate

216-B-62 B-Plant Prúcess Cundensale

216-C-7 209-E Critical Mass Laboratory

216-S-25 242-S Process Condensate

The four wells monitoring 216-A-37 Crib (299-E25-17, -18, -19, and -20$)$ were added to the monitoring network in 1980, and only one sample was collected from each well. Therefore, no trends for tritium concentrations have been established. Samples from the two wells (299-W23-9, -10) monitoring 216-S-25 Crib have been analyzed for tritium since 1974 (Figures 5 and 6). Tritium concentrations in Well 299-W23-10 reached a high early in 1980 in response to high tritium concentrations in the discharge to the 216-5-25 Crib in 1979 (Figure 7). This is a lag time of approximately 8 months. Tritium concentrations in the ground water are expected to rise in the early part of 1981 in response to the high (above $1,000 \mathrm{pCi} / \mathrm{mL}$ ) tritium concentrations discharged to the crib in February, June, Juiy, and August of 1980. 

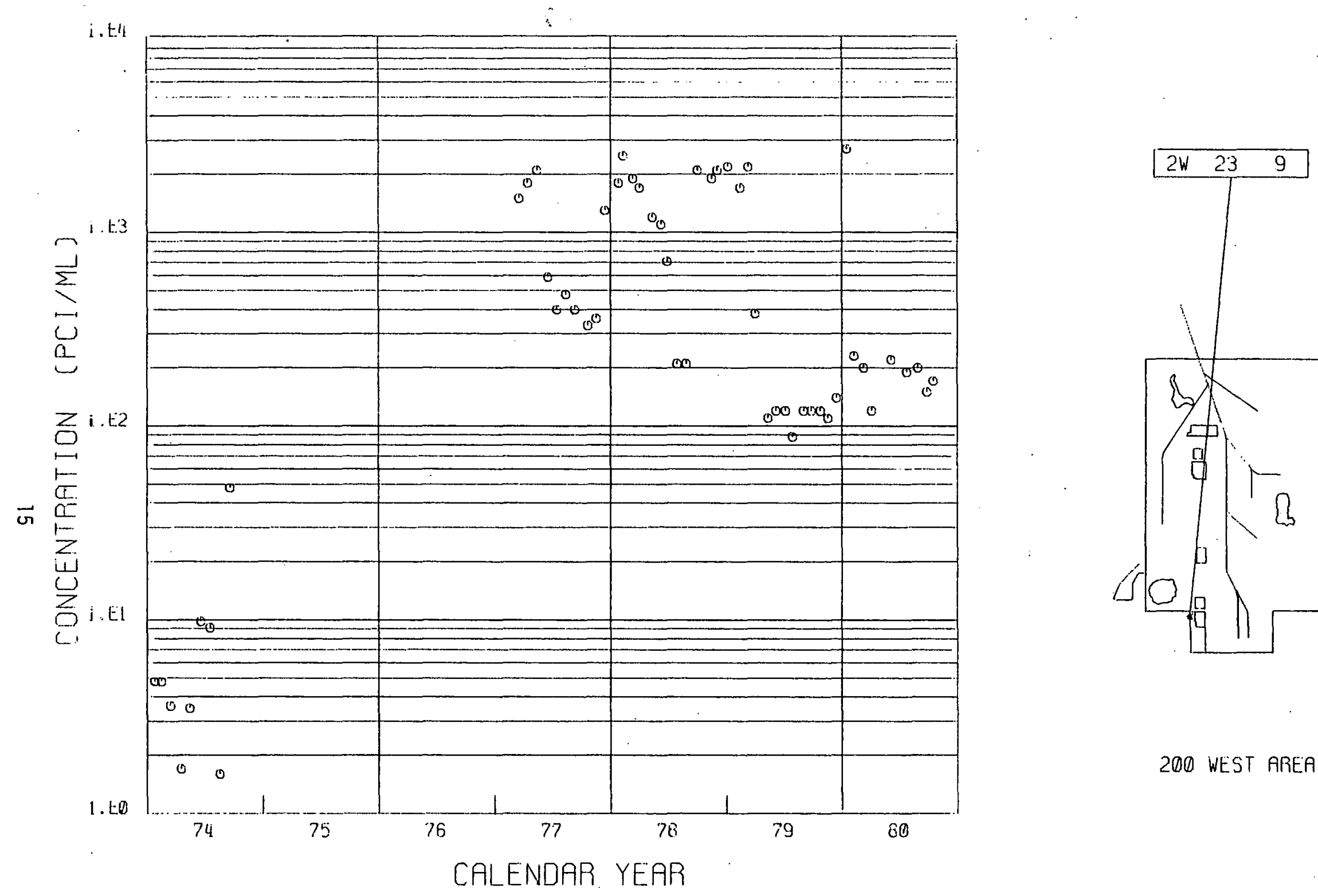

FIGURE 5. Well 299-W23-9 Tritium Concentration History Graph. 

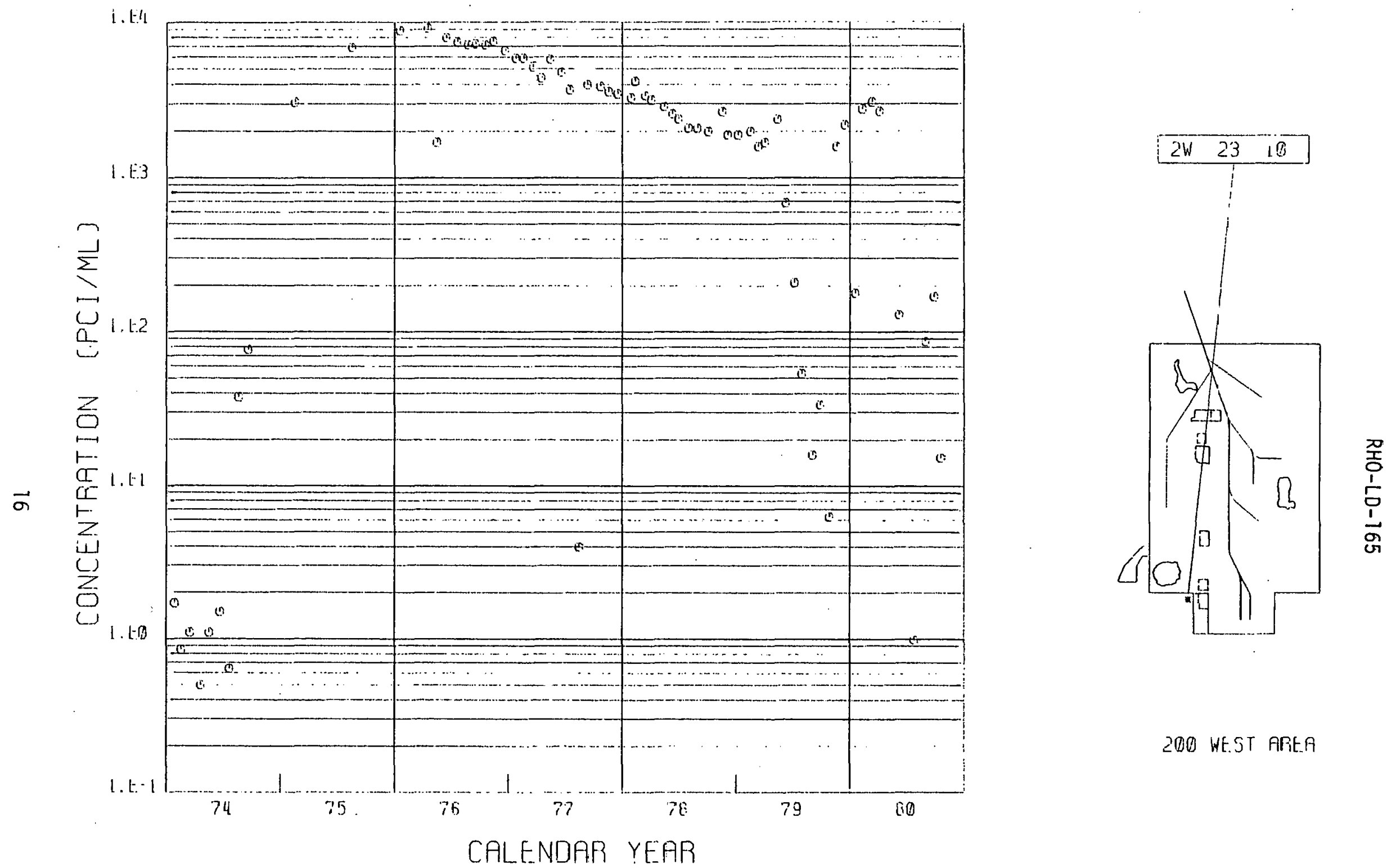

FIGURE 6. Wel1 299-W23-10 Tritium Concentration History Graph. 


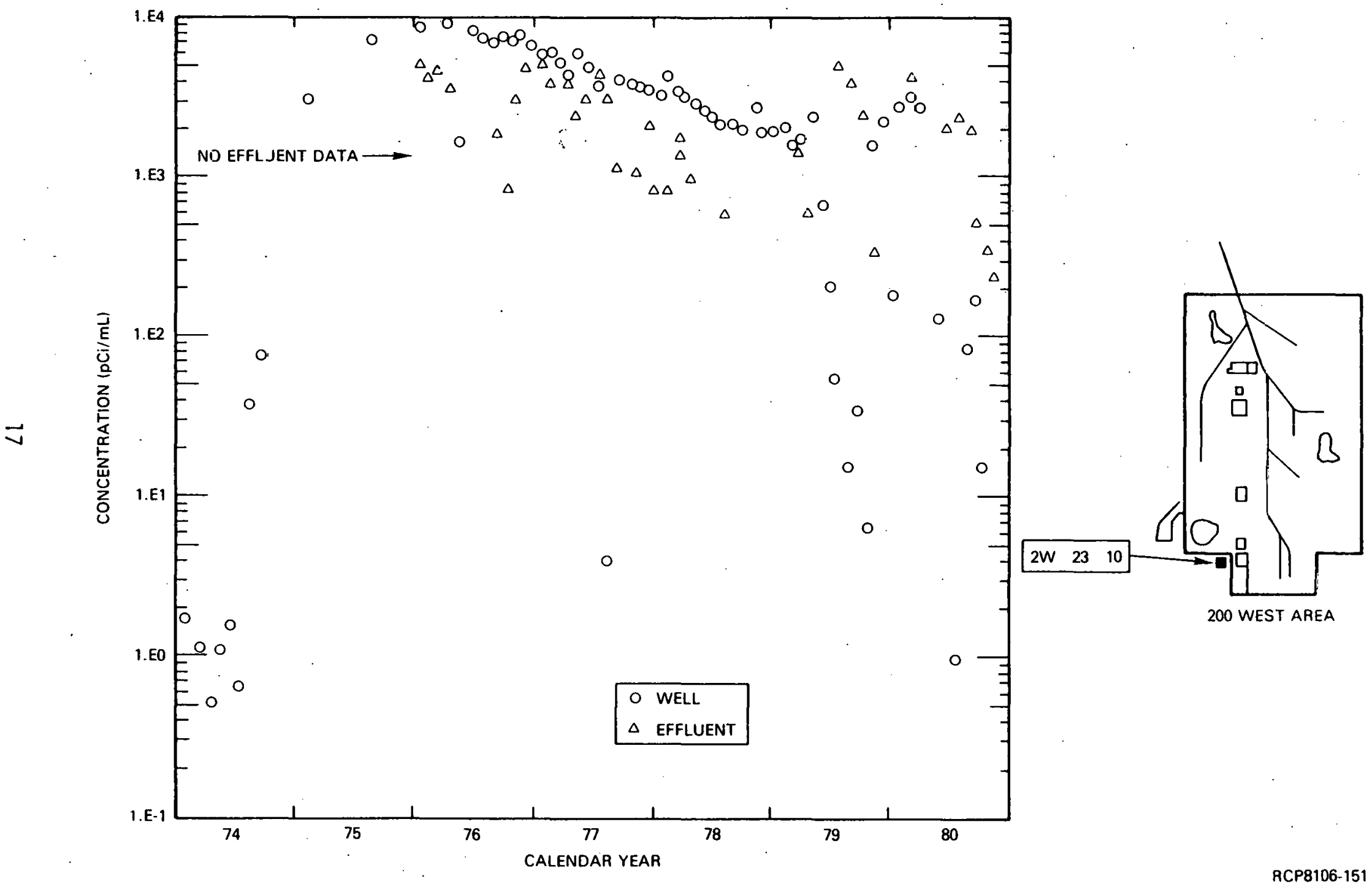

FIGURE 7. Tritium Concentration in Discharge to Crib 216-S-25 and Well 299-W23-10. 
Inactive Liquid-Waste Disposal Sites

With the exception of tritium, all of the contamination above $10 \%$ of Table II guidelines in the ground water under the Separations Area is the result of past disposal to sites which are no longer active. In 1980, there were two wells in the Separations Area ground-water monitoring network yielding samples which exceeded $10 \%$ of Table II values for 90Sr: 299-W19-3, monitoring 216-U-1 and -2 Crib; and 299-W22-1, monitoring 216-S-1 and -2 Crib. The concentration histories for ${ }^{90} \mathrm{Sr}$ in these wells are shown in Figures 8 and 9.

The 216:U-1 and -2 Crib, active from 1951 to 1967, received decontamination waste from 224-U Plant. There is more than an order of magnitude scatter in the ${ }^{90} \mathrm{Sr}$ data from Well 299-W19-3 monitoring 216-U-1 and -2; therefore, no trend can be determined. The 216-5-1 and -2 Crib, active from 195: to 1956 , was characterized to determine present radionuclide distributions and environmental safety. The ${ }^{90} \mathrm{Sr}$ contamination in the saturated zone is attributed to a casing failure of a water well within the crib. The concentrations of ${ }^{90} \mathrm{Sr}$ in 299-W22-1 have averaged around $2 \times 10^{1} \mathrm{pCi} / \mathrm{mL}$ since 1971 , exceedinly Table II guidelines and Table I guidelines for a controlled area. However, the zone of contamination appears to be stable and highly localized.

No samples contained concentrations of ${ }^{137} \mathrm{Cs},{ }^{60} \mathrm{Co}$, and ${ }^{106} \mathrm{Ru}$ above $10 \%$ of Table II limits. Only the one we11, 299-W23-10, exceeded Table II limits for tritium.

The $4.5-\mathrm{mg} / \mathrm{L}$ Environmental Protection Agency (EPA) drinking water standard for nitrate (as $\mathrm{NO}_{3}^{-}$) was exceeded in samples from seven wells in the Separations Area monitoring network (Table 2). Most of the concentrations followed a downward trend eslablislied since the facility being monitored was removed from service. However, the nitrate concentration history for Well 299-W75-4 (Figure 10) has been stable since the crib (216-T-19) was removed from service in 1976. Two wells located in the northwest corner of 200 East Area have nitrate concentration histories that indicate an upward trend in concentrations. This is attributed to the migration of contamination from other disposal sites into the area. 

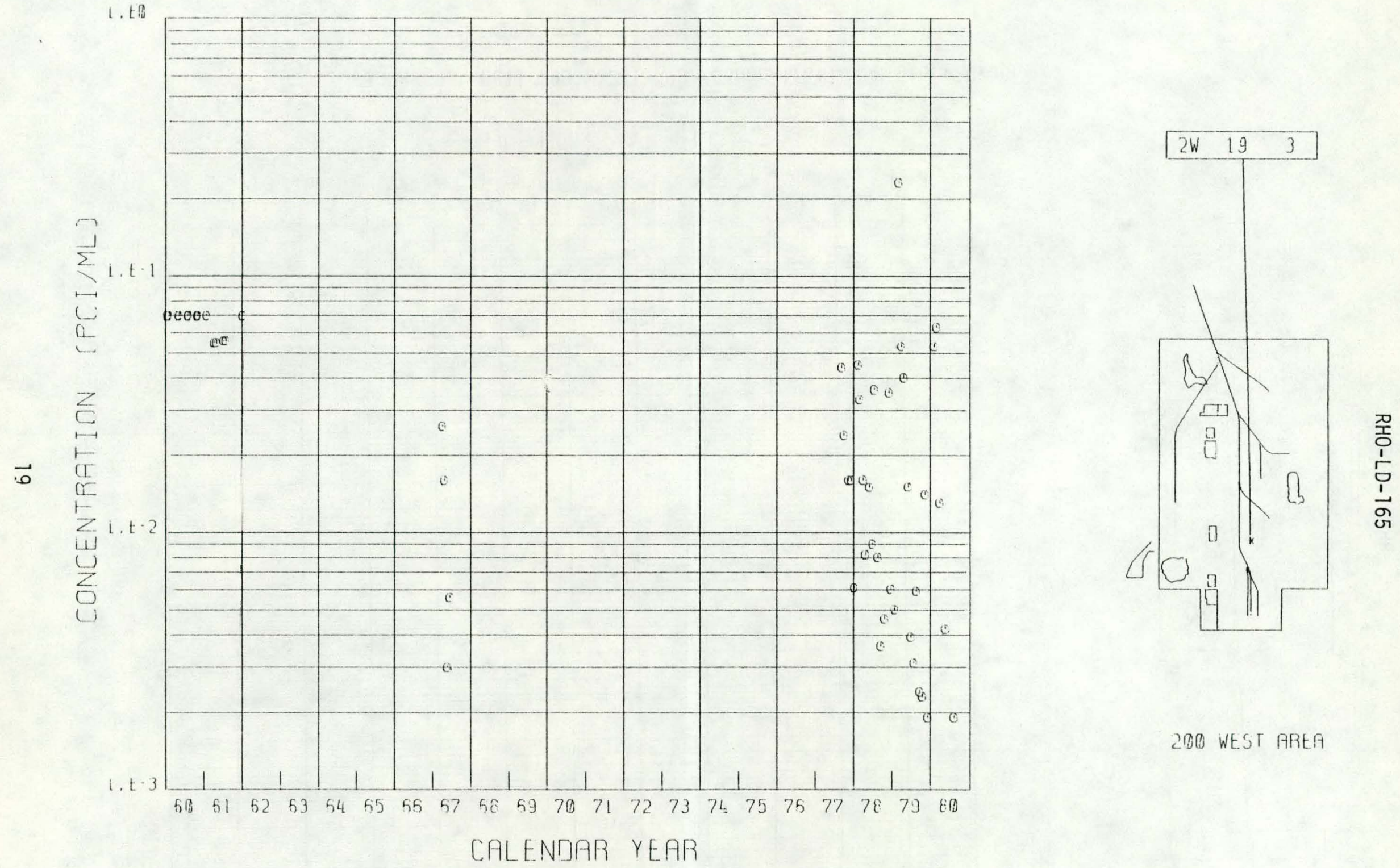

FIGURE 3. Wel1 299-W19-3 ${ }^{90} \mathrm{Sr}$ Concentration History Graph. 


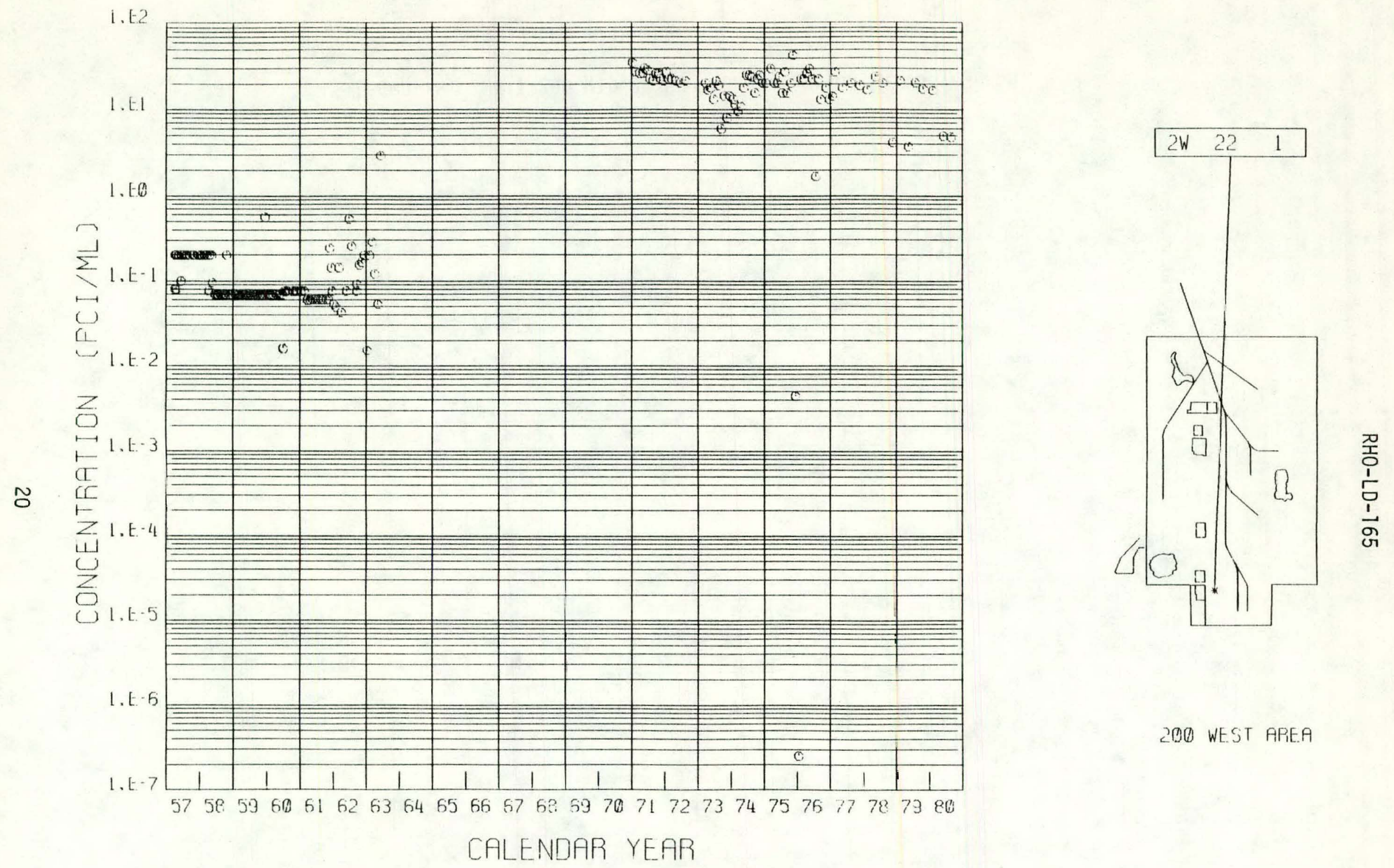

FIGURE 9. Well 299-W22-1 ${ }^{90} \mathrm{Sr}$ Concentration History Graph. 
RHO-LD'- 165

TABLE 2. Wells Yielding Samples. Exceeding $45 \mathrm{mg} / \mathrm{L}$ Nitrate.

\begin{tabular}{|c|c|c|c|}
\hline \multicolumn{2}{|c|}{ Well number } & Site monitored & $\underset{\mathrm{mg} / \mathrm{L}}{\text { Nitrate }}$ \\
\hline 2299-E17-9 & Mean & $216-A-36 B$ & $1.92 \times 10^{2 a}$ \\
\hline 299-E32-1 & $\begin{array}{l}\text { Mean } \\
\text { Max }\end{array}$ & 200 East Area & $\begin{array}{l}9.00 \times 10^{1 a} \\
4.30 \times 10^{2}\end{array}$ \\
\hline 299-E33-9 & $\begin{array}{l}\text { Mean } \\
\text { Min }\end{array}$ & 241-BY-Tank Farm & $\begin{array}{l}2.76 \times 10^{2} \\
1.40 \times 10^{2}\end{array}$ \\
\hline $299-W 14-2$ & $\begin{array}{l}- \text { Mean } \\
\text { Max }\end{array}$ & $216-T-26,-27,-28$ & $\begin{array}{l}1.98 \times 10^{2} \\
7.90 \times 10^{2}\end{array}$ \\
\hline 299-W15-4 & $\begin{array}{l}\text { Mean } \\
\text { Min }\end{array}$ & $216-T-19$ & $\begin{array}{l}7.28 \times 10^{2} \\
6.50 \times 10^{2}\end{array}$ \\
\hline $299-W 15-6$ & $\begin{array}{l}\text { Max } \\
\text { Mean } \\
\text { Min }\end{array}$ & $216-z-9$ & $\begin{array}{l}7.10 \times 10^{1} \\
2.03 \times 10^{1} \\
1.90 \times 10^{1}\end{array}$ \\
\hline 299-W19-2 & $\begin{array}{l}\text { Max } \\
\text { Mean } \\
\text { Min }\end{array}$ & $216-U-8$ & $\begin{array}{l}1.60 \times 10^{2} \\
8.26 \times 10^{1} \\
2.00 \times 10^{-1}\end{array}$ \\
\hline
\end{tabular}

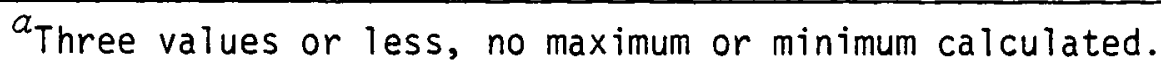

CONTAMINATION PLUMES

Contamination plumes are drawn for total beta, nitrate, and tritium (Figures 11,12 , and 13). These maps are constructed using the average concentrations of the constituents in samples taken in 1980 from wells in the Separations Area ground-water monitoring network. 'Data from the Hanford ground-water monitoring network for 1980 (Eddy and Wilbur, 1981) are also used. 

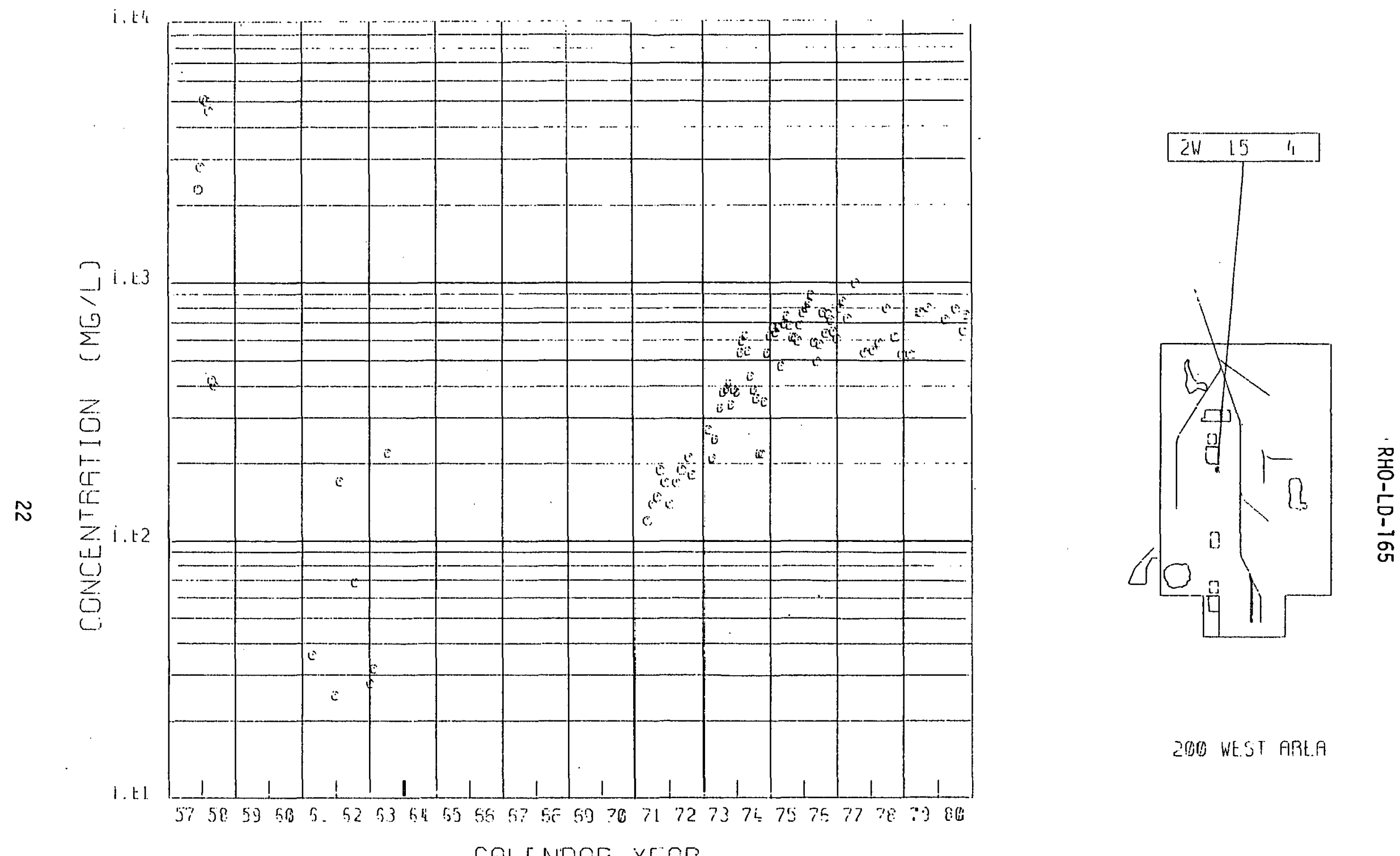

CALENDAF: YEARI

FIGURE 10. Well 29:3-WT5-4 Nitrate Concentration History' Graph. 


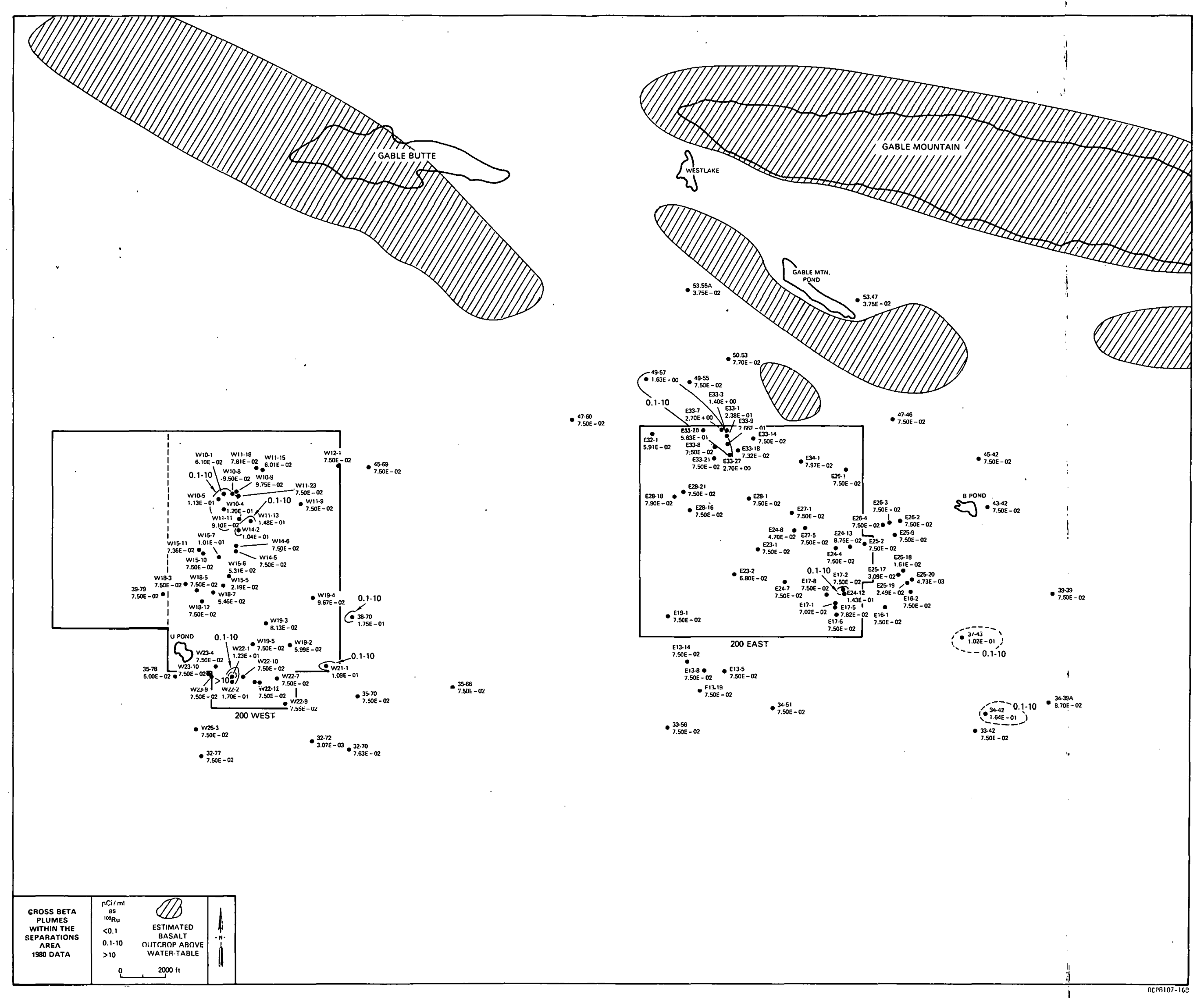

FIGURE 11. Gross Beta Plume Map - Separations Area.

23/24 blank 


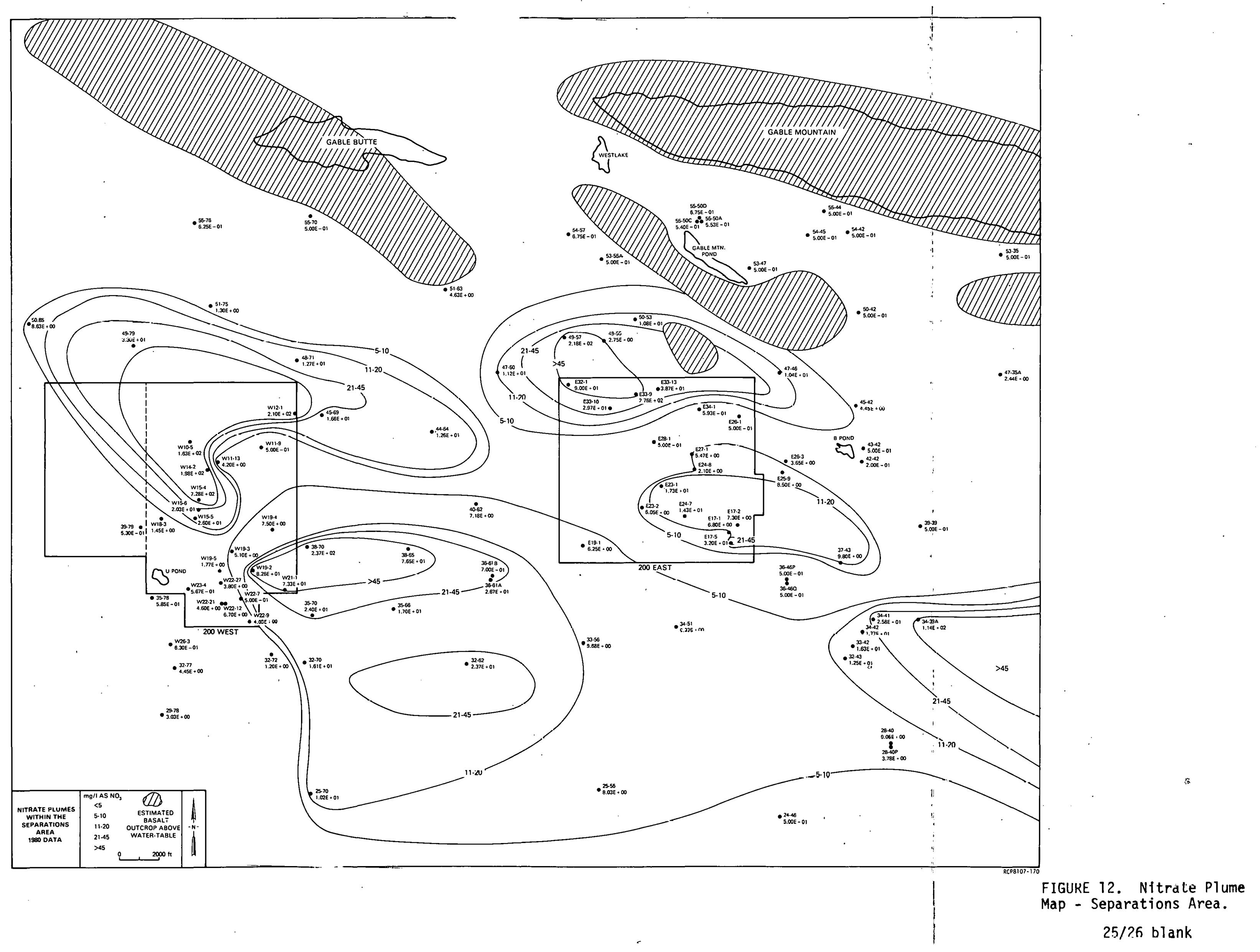




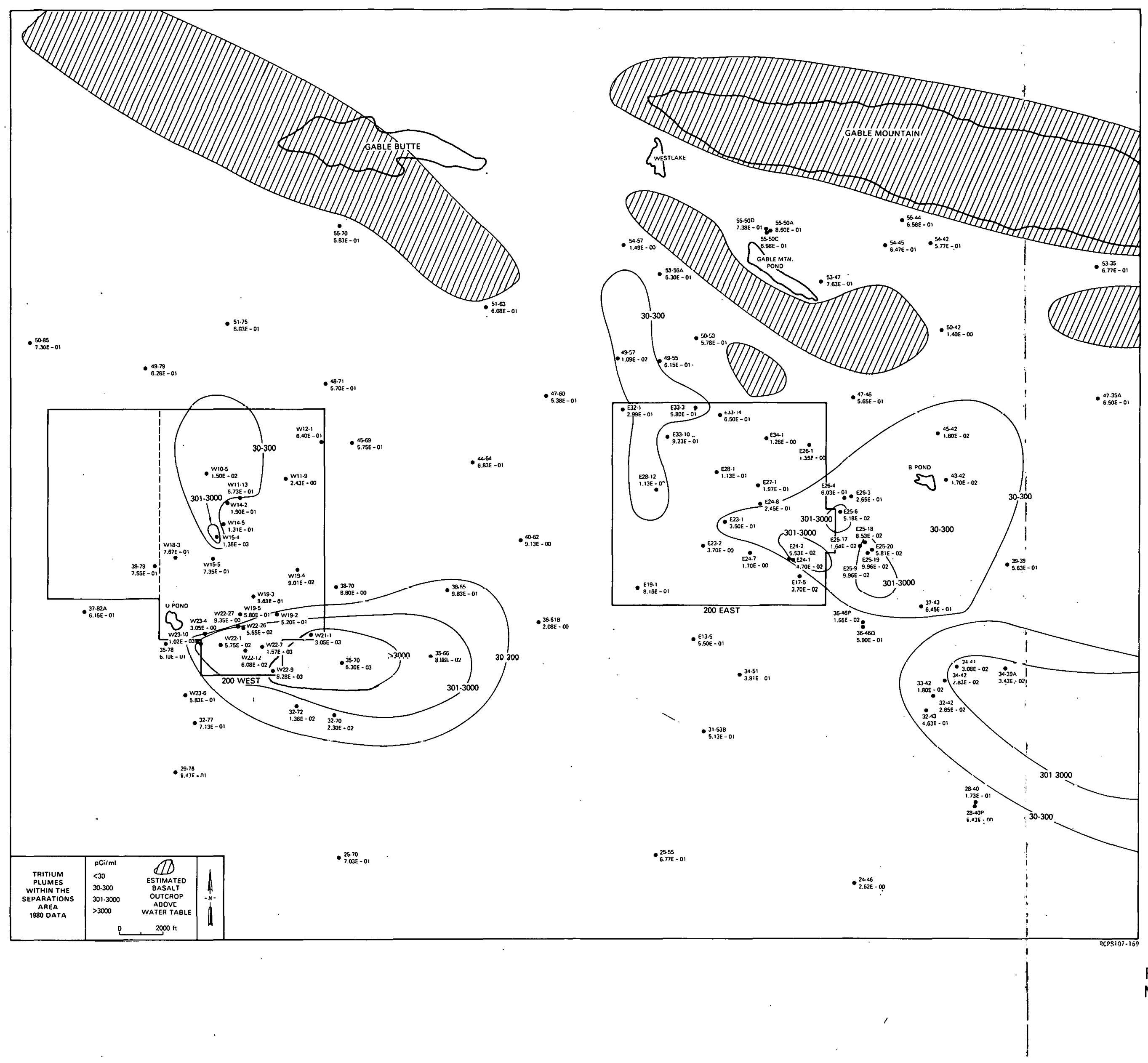




\section{Total Beta Contamination}

Total beta contamination is divided into three ranges: less than $0.1,0.1$ through 10; and greater than $10 \mathrm{pCi} / \mathrm{mL}$ (see Figure 11). Beta contamination is restricted to a few small areas. In 200 West Area, the sources of total beta contamination in the ground water are the 216-S, $-U$ and $-T$ Cribs; the highest beta activity is from the 216-S- 1 and -2 Crib. In 200 East Area, there are total beta plumes from the 216-BY and 216-A Cribs. The plume from the 216-BY Cribs is elongated in the direction of ground-water flow to the northwest. The beta contamination in Well 699-34-42 southeast of 200 East Area is contamination from past disposal practices that has migrated away from its source.

\section{Nitrate Contamination}

The nitrate contamination plumes are divided into five concentration ranges: less than 5, 5 through 10, 11 through 20, 21 through 45, and greater than $45 \mathrm{mg} / \mathrm{L}$ (see Figure 12). The EPA drinking water standard for nitrate $\left(\right.$ as $\mathrm{NO}_{3}^{-}$) is $45 \mathrm{mg} / \mathrm{L}$. The nitrate in the unconfined aquifer originated from $216-S,-T$, and $-U$ Cribs in 200 West Area; and from 216-BY and 216-A Cribs in 200 East Area. This nitrate is thought to be primarily from nitric acid used to dissolve the claddings on fuel rods in the process plants. The EPA drinking water standard is exceeded in four areas: north 200 West Area, the southeast corner and east"of 200 West Area, north of 200 East Area, and southeast of 200 East Area.

\section{Tritium Contamination}

Tritium contamination is divided into four ranges: less than 30 , 30 through 300,301 through 3,000, and greater than $3,000 \mathrm{pCi} / \mathrm{mL}$ (see Figure 13). The Table II guideline for tritium is $3,000 \mathrm{pCi} / \mathrm{mL}$. In 200 West Area, the tritium plumes originate from the 216-S, $-U$, and - T Cribs. The tritium contamination has moved approximately 5 kilometers ( 3 miles) from the $216-\mathrm{S}$ and $216-\mathrm{U}$ Cribs in 35 years. This indicates a ground-water flow velocity of 0.4 meter/day ( 1.3 feet/day), 
which is in general agreement with previous estimates (firaham et al., 1981). At that velocity, the tritium plume out of 200 West Area will reach 200 East Area in approximately 13 years (1993).

The tritium contamination in 200 East Area originates from the 216-BY and 216-A Cribs, and B-Pond. The tritium plumes from 200 East Area disposal sites have migrated farther than tritium from 200 West Area because the aquifer is located in the more transmissive Hanford formation sediments of the 200 East Area.

The only area exceeding Table II guidelines is a zone southeast of 200 Wcst Arca of approximately 0.8 square kilometer ( 0.5 square mile). 
SUMMARY

There are 107 water quality monitoring wells in the Separations Area ground-water monitoring network. This represents an increase of 10 wells over last year's network. Two new monitoring wells were drilled in 1980 and are scheduled to be added to the network in 1981.

A water-level monitoring network in the confined and unconfined aquifers is also maintained. Water-table maps and depth-to-water-table maps are produced semiannually for 200 East and 200 West Areas; a watertable map for the Hanford Site is produced annually. In addition, a water-table map for the Separations Area is produced for this document.

Samples from the water quality monitoring wells are collected at intervals ranging from monthly to semiannually. These samples are analyzed selectively for total alpha, total beta, ${ }^{60} \mathrm{Co},{ }^{106} \mathrm{Ru},{ }^{137} \mathrm{Cs}$, ${ }^{90} \mathrm{Sr}$, tritium, uranium, and nitrate. Review of the 1980 results indicates little differences from the 1979 results. The Table II guideline for tritium of 3,000 $\mathrm{pCi} / \mathrm{mL}$ was exceeded in We11. 299-W23-10, which monitors the active 216-S-25 Crib. This guideline was exceeded in one sample; subsequent samples were below this guideline.

With the exception of tritium, all contamination above $10 \%$ of Table II guidelines in the ground water under the Separations Area is the result of past disposal to sites which are no longer active. The onily samples with contamination in excess of guidelines were collected from We11 299-W22-1, monitoring the inactive 216-S-1 and -2 Crib. However, the zone of contamination appears to be stable and highly localized.

Analys is of contamination plumes within the Separations Area indicates that contamination levels in ground water migrating out of the Separations Area are below the DOE Table II guidelines. 
RHO-LD-165

BIBLIOGRAPHY

Eddy, P. A. and J. Scott Wilbur (1981), Radiological Status of the Ground Water Beneath the Hanford Project for 1980, PNL-3768, Pacific Northwest Laboratory, Richland, Washington.

Graham, M. J. (1981), The Radionuclide Ground-Water Monitoring Program for the Separations Area, Hanford Site, Washington State, RHO-SA-216, Rockwell Hanford Operations, Richland, Washington.

Graham, M. J. et al. (1981), Hydrology of the Separations Area, RHO-ST-42, Rockwell Hanford Operations, Richland, Washington.

Routson, R. C., G. S. Barney, and R. D. Seil (1979), Measurement of Fission Sorption Parameters for Hanford 200 Area Sediment Types, RHO-LD-73, Rockwell Hanford Operations, Richland, Washington.

Tallman, A. M., K. R. Fecht, M. C. Marratt, and G. V. Last (1979), Geology of the Separations Areas, Hanford Site, South-Central Washington, RHO-ST-23, Rockwell Hanford Operations, Richland, Washington.

United States Testing Company, Inc. (1980), Procedure Manual, (UST-RL-PM-9-80), United States Testing Company, Inc., Richland, Washington.

U.S. Department of Energy (1981), Environmental Protection, Safety, and Health Protection Information Reporting Results, 5480.1, Chapter XI, Richland, Washington. 
RHO-LD- 165

APPENDIX A

ROCKWELL GROUND-WATER MONITORING SCHEDULE FOR THE SEPARATIONS AREA 


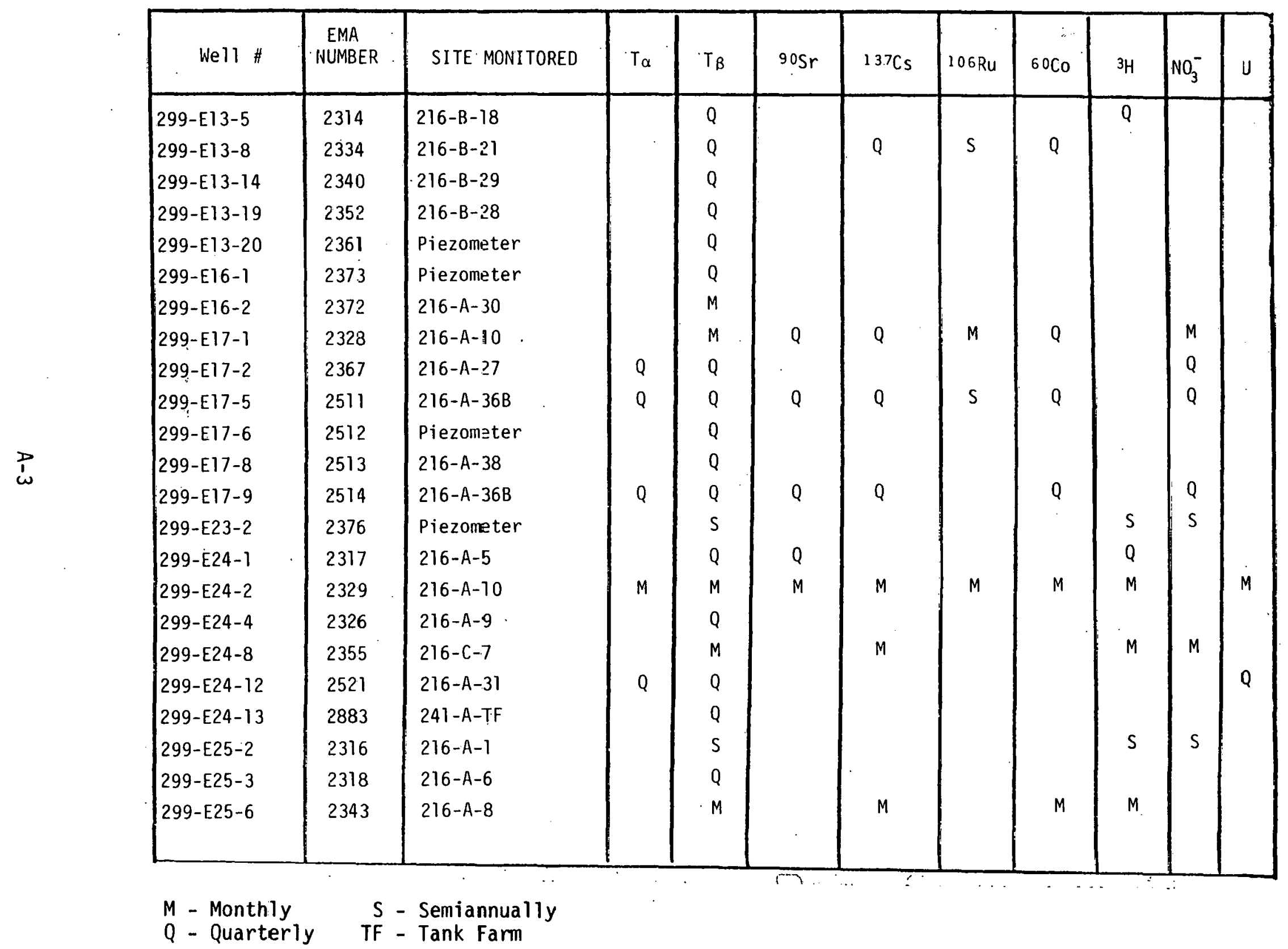




\begin{tabular}{|c|c|c|c|c|c|c|c|c|c|c|c|}
\hline Well \# & $\begin{array}{l}\text { EMA } \\
\text { NUMBER }\end{array}$ & SITE MONI TORED & $T_{\alpha}$ & $T_{\beta}$ & $90 \mathrm{Sr}$ & $1{ }^{137} \mathrm{Cs}$ & $106 R u$ & $60 \mathrm{CO}^{2}-2$ & $3 \mathrm{H}$ & $\mathrm{NO}_{3}^{-}$ & u \\
\hline 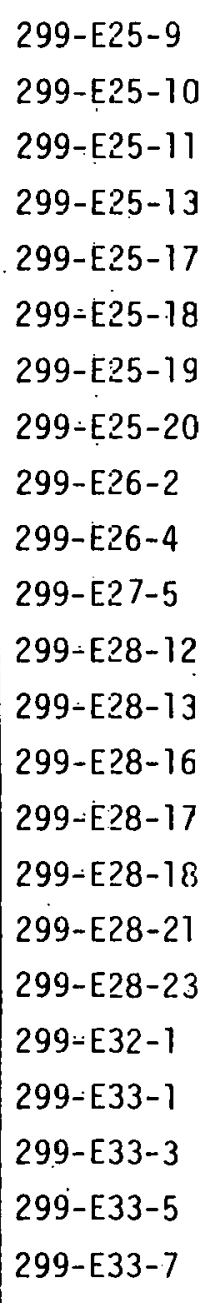 & $\begin{array}{l}2344 \\
2363 \\
2370 \\
2523 \\
\\
\\
\\
. \\
2364 \\
2362 \\
2351 \\
2380 \\
2324 \\
2325 \\
2519 \\
2524 \\
2556 \\
\\
2358 \\
2301 \\
2303 \\
2308 \\
2305\end{array}$ & $\begin{array}{l}216-A-8 \\
216-A-18,19,20 \\
216-A-30 \\
241-A X-T F \\
216-A-37 \\
216-A-37 \\
216-A-37 \\
216-A-37 \\
216-A-24 \\
216-A-24 \\
216-C-10 \\
216-B-55 \\
216-B-55 \\
216-B-12 \\
216-B-6,10 A, 1 C B \\
216-B-62 \\
216-B-62 \\
216-B-5 \\
\text { Background } \\
216-B-43 \\
216-B-44,45,4 E \\
216-B-47 \\
216-B-48,49,51\end{array}$ & $\begin{array}{l}Q \\
M \\
M \\
Q\end{array}$ & $\begin{array}{l}0 \\
Q \\
Q \\
Q \\
M \\
M \\
M \\
M \\
Q \\
Q \\
Q \\
M \\
M \\
Q\end{array}$ & $\begin{array}{l}M \\
M \\
Q\end{array}$ & $\begin{array}{l}M \\
M \\
Q \\
Q \\
Q \\
Q \\
Q\end{array}$ & s & $\begin{array}{l} \\
Q \\
Q \\
Q \\
Q\end{array}$ & $\begin{array}{l}M \\
M \\
M \\
M\end{array}$ & $\begin{array}{l}Q \\
S\end{array}$ & $Q$ \\
\hline
\end{tabular}




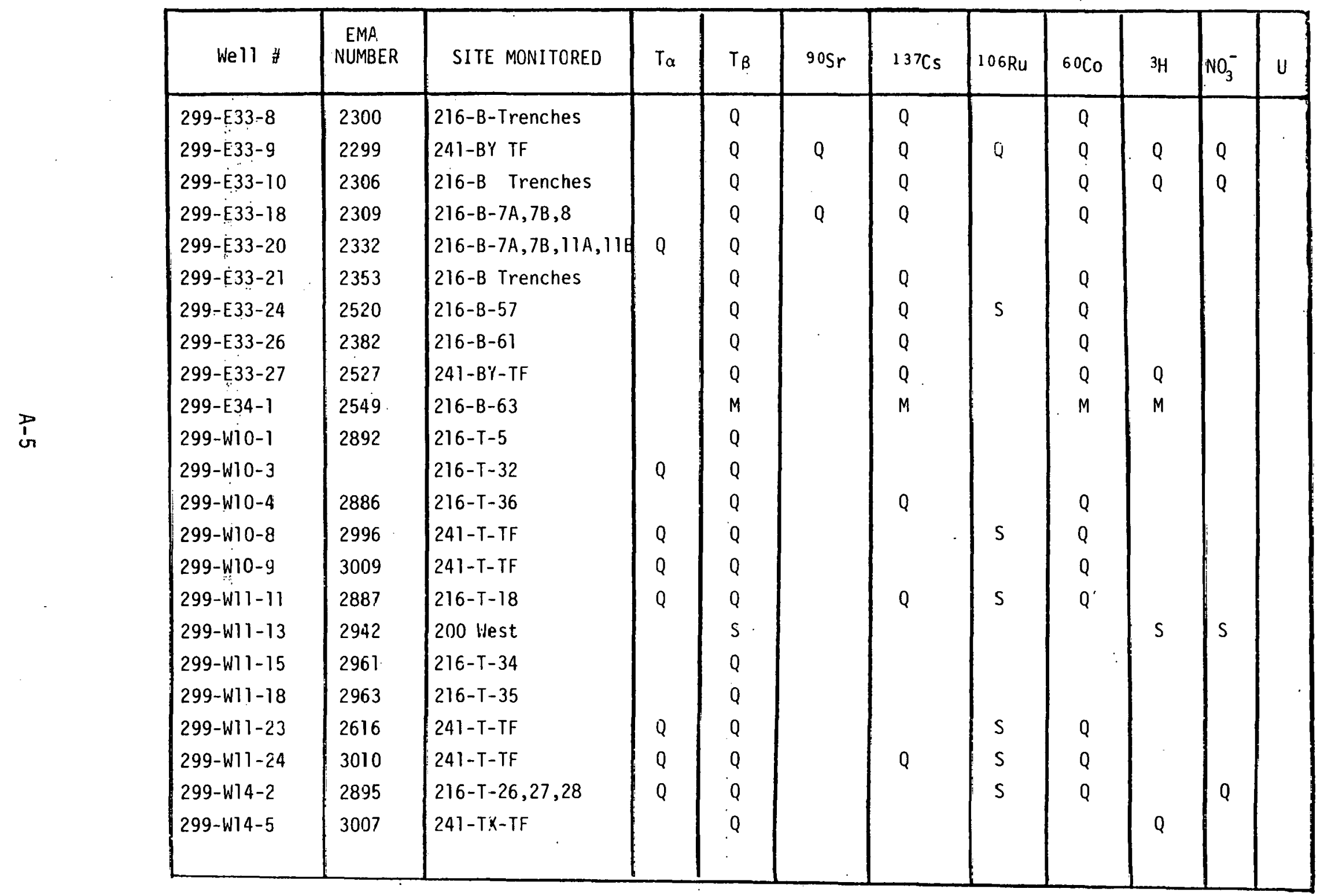




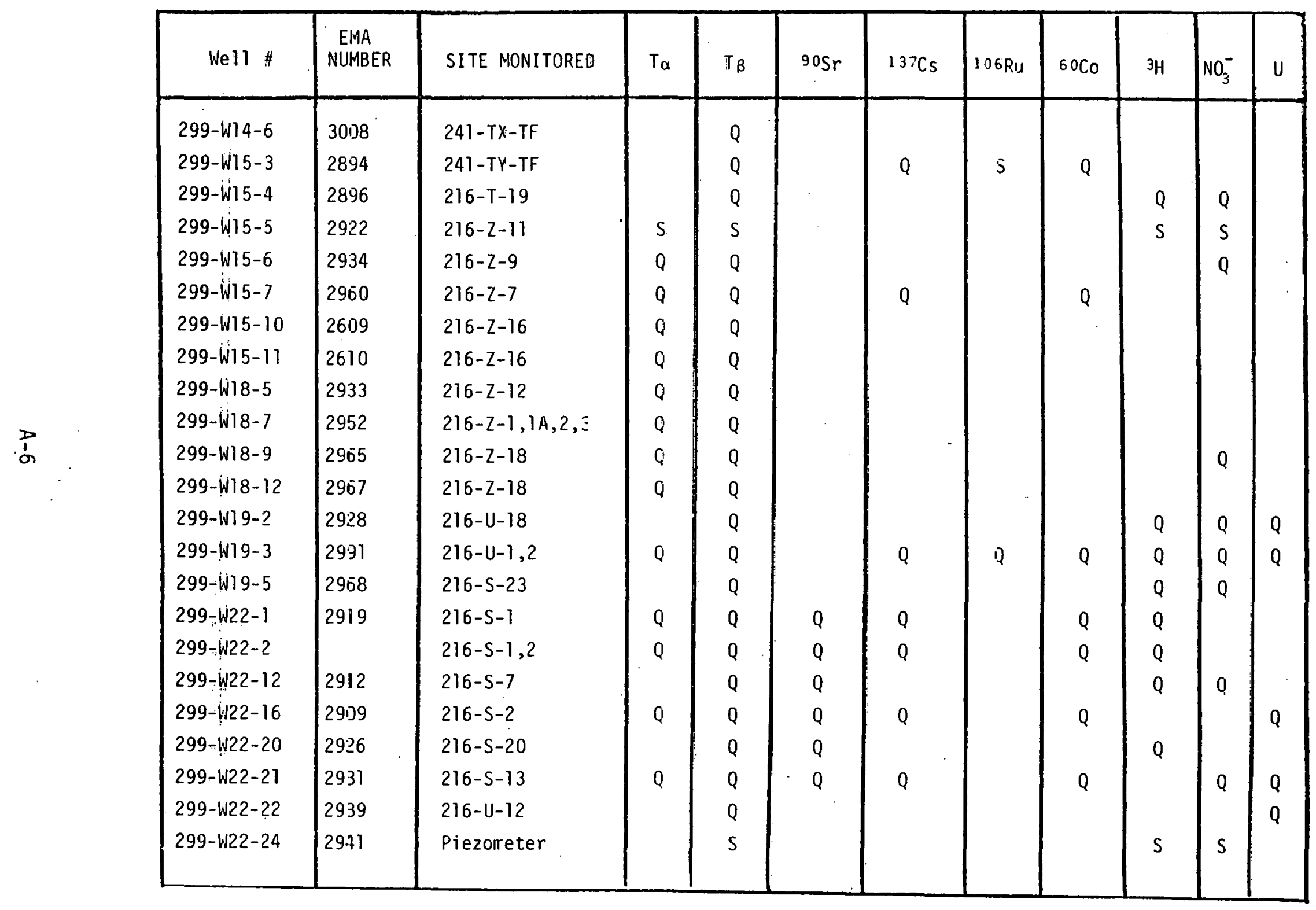

\begin{tabular}{l} 
꽁 \\
1 \\
$\vdots$ \\
\hline 1 \\
욥.
\end{tabular} 


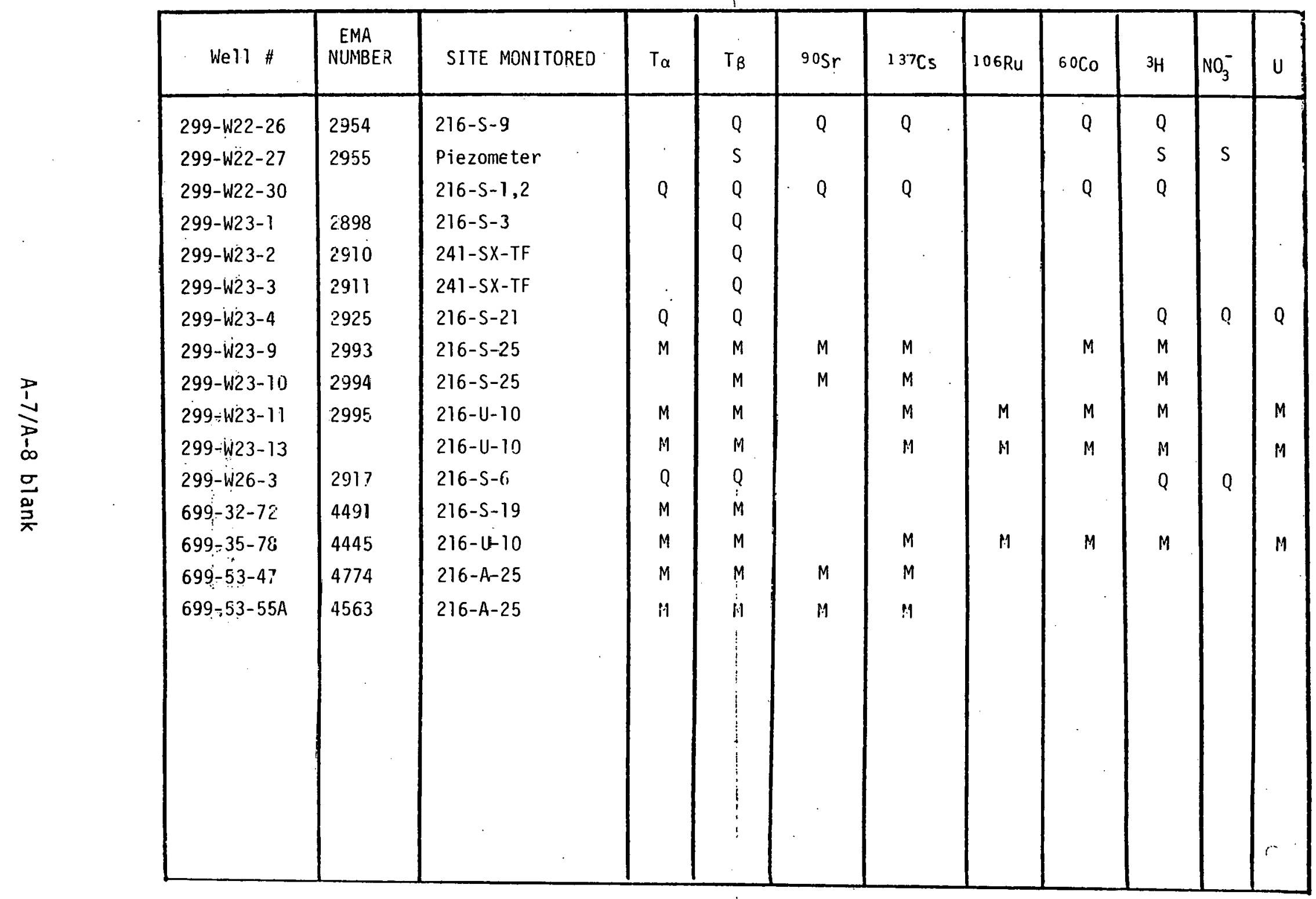


RHO-LD-165

\section{APPENDIX B}

WATER-LEVEL MONITORING WELL NETWORKS 
RHO-LD-165

Rockwell Confined Aquifer Water-Level Monitoring Network

\begin{tabular}{|c|c|}
\hline Well Number & Aquifer \\
\hline $699-516-24(D B-7)$ & Mabton \\
\hline $699-2-E-14(D B-1)$ & Mabton \\
\hline $699-15-E 13(D B-2)$ & Mabton \\
\hline $699-17-47(D B-13)$ & Mabton \\
\hline $699-35-27(D B-4)$ & Mabton \\
\hline $699-42-42(D B-8)$ & Rattlesnake Ridge \\
\hline $699-47-50$ & Rattlesnake Ridge \\
\hline $699-49-86 A \quad(D C-5)$ & Grand Ronde \\
\hline $699-49-86 B(D C-4)$ & Grand Ronde \\
\hline $699-50-45$ & Rattlesnake Ridge \\
\hline $699-50-48$ & Rattlesnake Ridge \\
\hline $699-50-112$ (Enyeart) & Priest Rapids 1 \\
\hline $699-51-36 A \quad(D B-10)$ & Mabton \\
\hline $699-52-46$ & Rattlesnake Ridge \\
\hline $699-52-48$ & Rattlesnake Ridge \\
\hline $699-52-52(\mathrm{DB}-5)$ & Mabton \\
\hline $699-52-111$ (Ford) & Priest Rapids 1 \\
\hline $699-52-115$ (0'Brien) & Priest Rapids 1 \\
\hline $699-53-50$ & Rattlesnake Ridge \\
\hline $699-53-103$ (McGee) & Priest Rapids $1 \& 2$ \\
\hline $699-59-58$ & Mabton \\
\hline $699-61-55$ & Mabton \\
\hline $699-62-57$ & Mabton \\
\hline
\end{tabular}


RHO-LD-165

Rockwell Unconfined Water-Levè] Measurement Network

\section{East Area}

$\begin{array}{llllll}299-E 13-3 & 299-E 19-1 & 299-E 25-3 & 299-E 26-4 & 299-E 28-12 & 299-E 33-12 \\ 299-E 13-10 & 299-E 23-1 & 299-E 25-4 & 299-E 27-1 & 299-E 28-18 & 299-E 33-14 \\ 299-E 13-12 & 299-E 24-1 & 299-E 25-9 & 299-E 27-3 & 299-E 32-1 & 299-E 33-17 \\ 299-E 13-13 & 299-E 24-4 & 299-E 25-11 & 299-E 28-7 & 299-E 33-7 & 299-E 33-21 \\ 299-E 16-1 & 299-E 24-7 & 299-E 26-1 & 299-E 28-8 & 299-E 33-8 & 299-E 34-1 \\ 299-E 17-1 & & & & & \end{array}$

200 West Area

\begin{tabular}{llllll}
\hline $299-W 6-1$ & $299-W 11-7$ & $299-W 11-23$ & $299-W 15-5$ & $299-W 19-4$ & $299-W 22-23$ \\
$299-W 10-2$ & $299-W 11-9$ & $299-W 12-1$ & $299-W 18-2$ & $299-W 21-1$ & $299-W 22-35$ \\
$299-W 10-5$ & $299-W 11-10$ & $299-W 14-1$ & $299-W 18-3$ & $299-W 22-7$ & $299-W 23-4$ \\
$299-W 10-8$ & $299-W 11-12$ & $299-W 15-2$ & $299-W 119-1$ & $299-W 22-17$ & $299-W 23-6$ \\
$299-W 11-2$ & $299-W 11-13$ & $299-W 15-4$ & $299-W 19-3$ & $299-W 22-22$ & $299-W 23-11$
\end{tabular}

600 Area

$\begin{array}{llllll}699-14-E 6 T & 699-33-4 L & 699-35-66 & 699-50-19 & 699-60-60 & 699-69-45(0) \\ 699-14-38 & 699-S 31-1 & 699-35-70 & 699-50-28 B & 699-61-37 & 699-70-23 \\ 699-11-47 & 699-530-F 15 A & 699-35-78 & 699-50-30 & 699-61-41 & 699-70-68 \\ 699-13-15 A & 699-529-E 12 & 699-36-4 G R & 699-5042 & 699-61-62 & 699-71-30 \\ 699-15-26 & 699-S 27-E 14 & 699-36-61 A & 699-50-53 & 699-61-66 & 699-71-52 \\ 699-17-5 & 699-S 19-E 13 & 699-36-93(0) & 699-50-85 & 699-62-31 & 699-71-77 \\ 699-17-70 & 699-S 19-E 11 & 699-37-43 & 699-51-63 & 699-62-43 A & 699-72-73 \\ 699-19-4.3 & 699-S 18-E 2 & 699-37-82 A & 699-51-75 & 699-62-43 F & 699-72-88 \\ 699-19-47 A & 699-S 14-20 & 699-38-65 & 699-53-35 & 699-63-25 A & 699-72-92(0) \\ 699-20-E 5 T & 699-S 12-3 & 699-38-70 & 699-53-47 & 699-63-51 & 699-74-44 \\ 699-20-E 12 & 699-S 12-29 & 699-39-39 & 699-53-55 B & 699-63-58 & 699-74-48 \\ 699-20-20 & 699-S 17-E 12 A & 699-39-79(0) & 699-54-17 A & 699-63-90 & 699-73-61 \\ 699-20-39 & 699-S 8-19 & 699-40-1 & 699-54-19 & 699-63-92 & 699-77-36 \\ 699-20-82 & 699-S 7-34 & 699-40-33 & 699-54-34 & 699-64-27 & 699-77-54 \\ 699-20-1 T & 699-S 6-E 14 A & 699-40-62 & 699-54-57 & 699-64-62 & 699-78-62 \\ 699-24-33 & 699-S 6-40 & 699-41-23 & 699-55-21 & 699-65-22 & 699-80-43 S\end{array}$


Rockwell Unconfined Water-Level Measurement Network

600 Area Cont:

$\begin{array}{llllll}699-24-46 & 699-S 3-E 12 & 699-42-12 A & 699-55-40 & 699-65-38 & 699-81-38 \\ 699-25-25 & 699-S 3-25 & 699-43-42 & 699-55-44 & 699-65-50 & 699-81-58 \\ 699-25-70 & 699-2-3 & 699-43-89 & 699-55-50 C & 699-65-59 & 699-82-45 A \\ 699-26-15 & 699-3-45 & 699-44-64 & 699-55-60 B & 699-65-72 & 699-83-32 \\ 699-27-8 & 699-8-17 & 699-45-42 & 600-55-70 & 699-65-83 & 699-83-47 \\ 699-28-40 & 699-8-25 & 699-45-69 & 699-55-76 & 699-65-95 & 699-84-35 A \\ 699-28-52 & 699-8-32 & 699-46-21 & 699-55-89 & 699-66-23 & 699-86-42 \\ 699-29-78 & 699-9-E 2 & 699-47-35 B & 699-55-95 & 699-66-38(0) 699-87-55 \\ 699-31-31 & 699-10-E 12 & 699-47-46 & 699-55-25 & 699-66-39 & 699-89-35 \\ 699-31-53 B & 699-10-54 & 699-47-60 & 699-56-43 & 699-66-58 & 699-90-34 \\ 699-31-65 & 699-11-45 A & 699-48-7 & 699-57-29 B & 699-66-64 & 699-89-45 \\ 699-32-22 & 699-33-56 & 699-48-18 & 699-57-83 & 699-66-91 & 699-91-37 \\ 699-32-42 & 699-34-39 A & 699-48-71 & 699-58-24 & 699-66-103 & 699-92-49 \\ 699-32-43 & 699-34-41 & 699-49-13 & 699-59-32 & 699-67-51 & 699-97-43 \\ 699-32-62 & 699-34-42 & 699-49-28 & 699-59-58 & 699-67-86 & 699-99-42 \\ 699-32-70 & 699-34-51 & 699-49-55 & 699-59-80 B & 699-67-98 & \\ 699-32-72 & 699-34-88 & 699-49-57 & 699-60-32 & 699-68-105 & \\ 699-32-77 & 699-35-9 & 699-49-79 & 699-60-57 & 699-69-38 & \end{array}$

100 Areä

$199 \mathrm{~B} 4-1$

199 D2-5

$199 \mathrm{~F} 5-1$

$199 \mathrm{H} 3-1$

$199 \mathrm{~K}-11$ 
Piezometer Network Well-Completion Information (Sheet 1 of 3 ).

\begin{tabular}{|c|c|c|c|}
\hline We11 & $\begin{array}{c}\text { Casing } \\
\text { elevation } \\
\text { (ft above } \\
\text { m.s.l.) }\end{array}$ & Aquifer & $\begin{array}{l}\text { Perforation } \\
\text { depth } \\
\text { top/bottom } \\
(\mathrm{ft})\end{array}$ \\
\hline $699-2-33 A$ & 536.37 & Glaciofluvial & 130 to 180 \\
\hline$P$ & 536.65 & Lower Ringold & 350 to 370 \\
\hline$Q$ & 536.63 & $\begin{array}{l}\text { Lower and Middle } \\
\text { Ringold }\end{array}$ & 300 to 320 \\
\hline $699-10-E 12$ & 430.86 & Glaciofluvial & \\
\hline$P$ & 430.86 & Basal Ringold & \\
\hline$Q$ & 430.86 & Glacinfluvial & \\
\hline $6 y y-512-29$ & 487.68 & Middle Ringold & 83 to 175 \\
\hline$P$ & 487.68 & $\begin{array}{l}\text { Elephant Mountain } \\
\text { Basalt }\end{array}$ & 186 to 190 \\
\hline$Q$ & 487.68 & Lower Ringold & 152 to 157 \\
\hline $699-14-E 6 P$ & 458.44 & Basalt & 490 to 500 \\
\hline$Q$ & 457.91 & Basalt & 441 to 451 \\
\hline$R$ & 458.14 & Basal Ringold & 377 to 387 \\
\hline S & 457.77 & Middle Ringold & 284 to 294 \\
\hline $\mathrm{T}$ & 458.38 & Glaciofluvial & 111 to 121 \\
\hline $699-14-38$ & 514.89 & Midule Ringôld & 110 to 409 \\
\hline$P$ & 514.89 & Basal Ringold & 415 to 420 \\
\hline$Q$ & 514.89 & Middle Ringold & 175 to 180 \\
\hline $699-15-15 A$ & 547.14 & Glaciofluvial & 140 to 190 \\
\hline$P$ & 547.14 & Middle Ringold & 205 to 215 \\
\hline $\begin{array}{l}\text { 699-20-E5 } \\
\text { (Individual } \\
\text { Structure) }\end{array}$ & & & \\
\hline$P$ & 467.04 & Basal Ringold & 445 to 455 \\
\hline$Q$ & 466.89 & Lower Ringold & 408 to 418 \\
\hline$R$ & 467.47 & Middle Ringuld & 297 to 307 \\
\hline$s$ & 466.58 & Middle Ringold & 210 to 220 \\
\hline$T$ & 467.69 & Glaciofluvial & 113 to 123 \\
\hline
\end{tabular}


RHO-LD-165

Piezometer Network Well-Completion Information (Sheet 2 of 3 ).

\begin{tabular}{|c|c|c|c|}
\hline Well & $\begin{array}{l}\text { Casing } \\
\text { elevation } \\
\text { (ft above } \\
\text { m.s.1.) }\end{array}$ & Aquifer & $\begin{array}{l}\text { Perforation } \\
\text { depth } \\
\text { top/bottom } \\
\text { (ft) }\end{array}$ \\
\hline \multicolumn{4}{|l|}{$\begin{array}{l}699-24-1 \\
\text { (Individual } \\
\text { Structure) }\end{array}$} \\
\hline$P$ & 474.55 & Lower Ringold & 446 to 456 \\
\hline Q. & 475.29 & Middle Ringold & 327 to 337 \\
\hline$R$ & 476.03 & Middle Ringold & 304 to 314 \\
\hline $\mathrm{s}$ & 476.27 & Middle Ringold & 211 to 221 \\
\hline$T$ & 475.54 & Glaciofluvial & 124 to 134 \\
\hline $699-20-39$ & 539.98 & $\begin{array}{l}\text { Lower and Middle } \\
\text { Ringold }\end{array}$ & 130 to 490 \\
\hline$P$ & 539.98 & Basal Ringold & 608 to 618 \\
\hline $699-22-70$ & 674.96 & $\begin{array}{l}\text { Rattlesnake Ridge } \\
\text { and Glaciofluvial }\end{array}$ & $\begin{array}{l}\text { cased to } \\
230\end{array}$ \\
\hline$P$ & 614.96 & Pomona Basalt & 315 to 320 \\
\hline$Q$ & 674.96 & $\begin{array}{l}\text { Rattlesnake Ridge } \\
\text { Interbed }\end{array}$ & 260 to 265 \\
\hline $699-28-40$ & 559.44 & Middle Ringold & 150 to 320 \\
\hline$P$ & 559.44 & Lower Ringold & 452 to 462 \\
\hline Q & 559.44 & Lower Ringold & 340 to 350 \\
\hline $699-31-31$ & 529.32 & Middle Ringold & 135 to 270 \\
\hline$P$ & 529.32 & Basal Ringold & 590 to 600 \\
\hline$Q$ & 529.32 & Lower Ringold & 360 to 370 \\
\hline $699-32-62$ & 707.09 & Middle Ringold & 275 to 340 \\
\hline$P$ & 707.09 & Middle Ringold & 490 to 495 \\
\hline Q & 707.09 & Middle Ringold & 365 to 370 \\
\hline $699-32-72$ & 668.16 & $\begin{array}{l}\text { Middle and Upper } \\
\text { Ringold }\end{array}$ & 210 to 415 \\
\hline$P$ & 668.16 & Lower Ringold & 465 to 470 \\
\hline $699-38-65$ & 753.33 & Middie Ringold & 220 to 440 \\
\hline$P$ & 753.33 & Middle Ringold & 500 to 510 \\
\hline
\end{tabular}


RHO-LD-165

Piezometer Network Well-Completion Information (Sheet 3 of 3 ).

\begin{tabular}{|c|c|c|c|}
\hline We11 & $\begin{array}{l}\text { Casing } \\
\text { elevation } \\
\text { (ft above } \\
\text { m.s.l.) }\end{array}$ & Aquifer & $\begin{array}{l}\text { Perforation } \\
\text { depth } \\
\text { top/bottom } \\
\text { (ft) }\end{array}$ \\
\hline $699-50-42$ & 466.84 & & 53 to 64 \\
\hline$P$ & 466.84 & & 110 to 115 \\
\hline $699-50-85$ & 739.35 & Middle Ringold & 285 to 335 \\
\hline$P$ & 739.35 & Lower Ringold & 520 to 525 \\
\hline $699-57-75$ & 641.51 & Middle Ringold & 190 to 235 \\
\hline$P$ & 641.51 & Middle Ringold & 370 to 375 \\
\hline $699-53-55 A$ & 575.60 & M4ddle Rłng̈old & 165 to $2 \%$ \\
\hline$P$ & 575.60 & Pomona Basalt & 330 to 335 \\
\hline $699-55-70$ & 569.03 & Middle Ringold & 136 to 180 \\
\hline$P$ & 569.03 & Middle Ringold & 190 to 195 \\
\hline $699-60-60$ & 512.03 & Middle Ringold & 100 to 110 \\
\hline$P$ & 512.03 & Middle Ringold & 120 to 125 \\
\hline $699-67-51$ & 524.49 & Middle Ringold & 100 to 170 \\
\hline $\mathrm{P}$ & 52.4 .2 .9 & Middle Ringnld & 230 to 2.35 \\
\hline$\eta$ & 524.54 & Middle Kingngld & 184 to 194 \\
\hline $699-96-49$ & 419.29 & Glaciofluvial & 28 to 60 \\
\hline$p$ & 419.29 & Middle Ringold & 79 to 89 \\
\hline
\end{tabular}

NOTE: Letter denotes piezometer tube in well. 
RHO-LD-165

APPENDIX C

WATER-LEVEL MEASUREMENT DATA FOR 1980 
RHO-LD-165

\begin{tabular}{|c|c|c|c|}
\hline We11 & $\begin{array}{c}\text { Casing } \\
\text { elevation } \\
\text { (ft above } \\
\text { m.s.1.) }\end{array}$ & $\begin{array}{l}\text { Depth to } \\
\text { water } \\
\text { (ft) }\end{array}$ & $\begin{array}{c}\text { Water level } \\
\text { elevation } \\
\text { (ft above } \\
\text { m.s.l.) }\end{array}$ \\
\hline $699-531-1$ & 460.11 & 85.19 & 374.92 \\
\hline 699-S30-E15A & 400.39 & 58.19 & 342.20 \\
\hline $699-S 29-E 12$ & 387.97 & 42.83 & 345.14 \\
\hline 699-\$27-ET4 & 399.77 & 57.74 & 342.03 \\
\hline 699-S19-E13 & 394.55 & 51.18 & 343.37 \\
\hline 699-\$19-E11 & 483.74 & 96.49 & 387.25 \\
\hline 699-S18-E2 . & 434.85 & 77.08 & 357.77 \\
\hline $699-514-20$ & 493.01 & 92.60 & $400 . .41$ \\
\hline $699-512-3$ & 435.52 & 57.35 & 378.17 \\
\hline $699-512-29$ & 487.68 & 83.09 & 404.59 \\
\hline $699-S I 1-E 12 A^{a}$ & 365.87 & 17.45 & \\
\hline $699-58-19$ & 503.81 & 109.32 & 394.49 \\
\hline $699-57-34$ & 527.12 & 120.98 & 406.14 \\
\hline 699-S6-E14A & 378.29 & 28.90 & 349.39 \\
\hline 699-S6-E4D & 430.47 & 59.97 & 370.50 \\
\hline 699-S3-E12 & 397.90 & 44.80 & 353.10 \\
\hline $699-\$ 3-25$ & 523.40 & 125.89 & 397.42 \\
\hline $699-2-3$ & 477.14 & 89.80 & 387.34 \\
\hline $699-3-45$ & 504.54 & 95.07 & 409.47 \\
\hline $699-8-17$ & 522.44 & 125.93 & 396.51 \\
\hline $699-8-25$ & 509.30 & 111.53 & 397.77 \\
\hline $699-8-32$ & 544.39 & 174.97 & 369.42 \\
\hline $699-9-E 2$ & 418.09 & 47.04 & 371.05 \\
\hline 699-10-E12 & 430.86 & 74.85 & 356.01 \\
\hline $699-10-54$ & 516.40 & 105.07 & 411.33 \\
\hline $699-11-45 A$ & 578.58 & 169.10 & 409.48 \\
\hline 699-14-E6T & 458.38 & 93.64 & 364.74 \\
\hline $699-14-38$ & 514.89 & 112.10 & 402.79 \\
\hline $699-14-47$ & 587.23 & 177.36 & 409.87 \\
\hline $699-15-15 A$ & 547.14 & 150.53 & 396.61 \\
\hline $699-15-26$ & 523.83 & 124.58 & 399.25 \\
\hline $699-17-5$ & 433.19 & 47.68 & 385.51 \\
\hline
\end{tabular}


RHO-LD-165

\begin{tabular}{|c|c|c|c|}
\hline Well & $\begin{array}{c}\text { Casing } \\
\text { elevation } \\
\text { (ft above } \\
\text { m.s.l.) }\end{array}$ & $\begin{array}{l}\text { Depth to } \\
\text { water } \\
\text { (ft) }\end{array}$ & $\begin{array}{c}\text { Water level } \\
\text { elevation } \\
\text { (ft above } \\
\text { m.s.l.) }\end{array}$ \\
\hline $699-17-70$ & 563.18 & 89.82 & 473.36 \\
\hline $699-19-43$ & 551.58 & 149.43 & 402.15 \\
\hline $699-19-47 A^{b}$ & 617.18 & & \\
\hline $699-20-E 5 T$ & 467.49 & 97.56 & 369.93 \\
\hline $699-20-E 12$ & 437.25 & 80.73 & 356.52 \\
\hline $699-20-20$ & 505.58 & 106.13 & 399.45 \\
\hline $699-20=39$ & 539.98 & 138.55 & 401.43 \\
\hline $699-20-82^{c}$ & 614.31 & & \\
\hline $699-24-1 T$ & 475.54 & 101.10 & 374.44 \\
\hline $699-24-33$ & 524.22 & 122.95 & 401.27 \\
\hline $699-24-46$ & 591.47 & 188.03 & 403.44 \\
\hline $699-25-55$ & 676.55 & 264.55 & 472.00 \\
\hline $699-25-70$ & 629.58 & 177.15 & 452.43 \\
\hline $699-26-15$ & 442.64 & 45.75 & 396.89 \\
\hline $699-27-8$ & 465.67 & 73.39 & 392.20 \\
\hline $699-28-40$ & 559.44 & 157.62 & 401.82 \\
\hline $699-28-52$ & 684.67 & $275.4 \dot{9}$ & 409.18 \\
\hline $699-29-78$ & 647.05 & 176.04 & 471.01 \\
\hline $699-31-31$ & 529.32 & 128.04 & 401.28 \\
\hline $699-31-53 B$ & 707.86 & 304.72 & 403.14 \\
\hline $699-31-65^{d}$ & 683.09 & & \\
\hline $699-32-22$ & 517.55 & 118.35 & 399.20 \\
\hline $699-32-42$ & 517.42 & 119.09 & 398.33 \\
\hline $699-32-43$ & 516.62 & 114.69 & 401.93 \\
\hline $699-32-6 ?$ & 707.09 & 276.87 & 430.22 \\
\hline $699-32-70$ & 666.61 & 210.01 & 456.60 \\
\hline $699-32-72$ & 668.16 & 209.40 & 458.76 \\
\hline $699-32-77$ & 653.74 & 183.31 & 470.43 \\
\hline $699-33-42$ & 516.00 & 114.00 & 402.00 \\
\hline $699-33-56$ & 717.03 & 373.90 & 403.13 \\
\hline $699-34-39 A$ & 537.07 & 135.17 & 401.90 \\
\hline $699-34-41$ & 570.89 & 168.89 & 402.00 \\
\hline
\end{tabular}


RHO-LD-165

\begin{tabular}{|c|c|c|c|}
\hline Well & $\begin{array}{c}\text { Casing } \\
\text { elevation } \\
\text { (ft above } \\
\text { m.s.l.) }\end{array}$ & $\begin{array}{l}\text { Depth to } \\
\text { water } \\
\text { (ft) }\end{array}$ & $\begin{array}{c}\text { Water level } \\
\text { elevation } \\
\text { (ft above } \\
\text { m.s.l.) }\end{array}$ \\
\hline $699-34-42$ & 540.20 & 138.31 & 401.89 \\
\hline $699-34-51$ & 736.76 & 334.38 & 402.38 \\
\hline $699-34-88$ & 633.09 & 158.36 & 474.73 \\
\hline $699-35-9$ & 499.83 & 116.22 & 383.61 \\
\hline $699-35-66$ & 725.65 & 283.69 & 441.96 \\
\hline $699-35-70^{e}$ & 693.72 & 237.66 & 456.06 \\
\hline $699-35-78$ & 660.65 & 182.86 & 477.79 \\
\hline $699-36-46 R$ & 705.13 & 302.09 & 403.04 \\
\hline $699-36-61 A$ & 748.11 & 339.48 & 408.63 \\
\hline $699-36-93(0)$ & 645.03 & 170.80 & 474.23 \\
\hline $699-37-43$ & 690.17 & 287.74 & 402.43 \\
\hline $699-37-82 A$ & 636.75 & 162.19 & 474.56 \\
\hline $699-38-65$ & 753.33 & 320.41 & 432.92 \\
\hline $699-38-70$ & 710.67 & 252.74 & 457.93 \\
\hline 699-39-39 & 536.66 & 129.32 & 407.34 \\
\hline $699-39-79(0)$ & 674.27 & 196.17 & 478.10 \\
\hline $699-40-1$ & 437.77 & 74.58 & 363.19 \\
\hline $699-40-33$ & 518.05 & 110.65 & 407.40 \\
\hline $699-40-62$ & 747.78 & 342.12 & 405.66 \\
\hline $699-41-23$ & 466.50 & 70.10 & 396.40 \\
\hline $699-42-12 A$ & 514.27 & 140.02 & 371.25 \\
\hline $699-43-42$ & 564.48 & 145.92 & 418.56 \\
\hline $699-43-89$ & 644.15 & 175.06 & 469.09 \\
\hline $699-44-64$ & .725 .57 & 318.82 & 406.75 \\
\hline $699-45-42$ & 577.33 & 163.62 & 413.71 \\
\hline $699-45-69$ & 725.46 & 276.30 & 449.16 \\
\hline $699-46-21$ & 522.02 & 132.73 & 389.29 \\
\hline $699-47-35 B$ & 476.65 & 68.46 & 408.19 \\
\hline $699-47-46$ & 580.14 & 176.65 & 403.49 \\
\hline $699-47-60$ & 649.85 & 247.30 & 402.55 \\
\hline $\begin{array}{l}699-48-7 \\
\text { (HAN6) }\end{array}$ & 384.72 & 28.17 & 356.55 \\
\hline
\end{tabular}


RHO-LD-165

\begin{tabular}{|c|c|c|c|}
\hline We11 & $\begin{array}{c}\text { Casing } \\
\text { elevation } \\
\text { (ft above } \\
\text { m.s.l.) }\end{array}$ & $\begin{array}{c}\text { Depth to } \\
\text { water } \\
(\mathrm{ft})\end{array}$ & $\begin{array}{c}\text { Water level } \\
\text { elevation } \\
\text { (ft above } \\
\text { m.s.l.) }\end{array}$ \\
\hline $\begin{array}{l}699-48-18 \\
\text { (HAN24) }\end{array}$ & 424.98 & 63.45 & 361.53 \\
\hline $699-48-71$ & 688.15 & 241.47 & 446.68 \\
\hline $\begin{array}{l}699-49-13 \\
\text { (HAN19) }\end{array}$ & 412.72 & 51.88 & 360.84 \\
\hline $699-49-28$ & 535.41 & 143.26 & 392.15 \\
\hline $699-49-55$ & 530.14 & 127.72 & 402.42 \\
\hline $699-49-57$ & 552.81 & 150.39 & 402.42 \\
\hline $699 \cdot 49-79$ & 688.59 & 2.30 .36 & 458.23 \\
\hline $\begin{array}{l}699-50-19 \\
\text { (HAN27) }\end{array}$ & 411.08 & 50.05 & 361.03 \\
\hline $699-50-28 B$ & 537.30 & 145.47 & 391.83 \\
\hline $699-50-30$ & 528.84 & 136.59 & 392.25 \\
\hline $699-50-42$ & 466.84 & 58.80 & 408.04 \\
\hline $699-50-53$ & 556.30 & 153.85 & 402.45 \\
\hline $699-50-85$ & 739.35 & 282.72 & 456.63 \\
\hline $699-51-63$ & 571.84 & 167.05 & 404.79 \\
\hline $699-57-75$ & 641.51 & 191.41 & 450.10 \\
\hline $699-53-35$ & 530.99 & 137.03 & 393.96 \\
\hline $699-53-47$ & 438.28 & 27.20 & 411.08 \\
\hline $699-53-55 B$ & 576.13 & 174.17 & 401.96 \\
\hline $699-54-17 A^{f}$ & 404.35 & & \\
\hline $\begin{array}{l}699-54-19 \\
\text { (HAN8) }\end{array}$ & 383.60 & 22.47 & 361.13 \\
\hline $699-54-34$ & 550.24 & 143.51 & 406.73 \\
\hline $699-54-57$ & 577.78 & 172.44 & 405.34 \\
\hline $699-55-21$ & 395.96 & 37.80 & 358.16 \\
\hline $699-55-40$ & 543.13 & 135.89 & 407.24 \\
\hline $699-55-44$ & 519.67 & 125.60 & 394.07 \\
\hline $699-55-50 \mathrm{C}$ & 444.43 & 41.88 & 402.55 \\
\hline $699-55-60 B$ & 573.68 & 171.43 & 402.25 \\
\hline $699-55-70$ & 569.04 & 137.95 & 431.09 \\
\hline $699-55-76$ & 583.50 & 139.67 & 443.83 \\
\hline
\end{tabular}


RHO-LD-165

\begin{tabular}{|c|c|c|c|c|}
\hline Well & $\begin{array}{c}\text { Casing } \\
\text { elevation } \\
\text { (ft above) } \\
\text { m.s.1.) }\end{array}$ & & $\begin{array}{l}\text { Depth to } \\
\text { water } \\
(\mathrm{ft})\end{array}$ & $\begin{array}{c}\text { Water level } \\
\text { elevation } \\
\text { (ft above } \\
\text { m.s.l.) }\end{array}$ \\
\hline $699-55-89$ & 617.69 & & 163.77 & 453.92 \\
\hline $699-55-95$ & 777.04 & & 311.50 & 465.54 \\
\hline $699-57-25$ & 414.61 & 1 & 53.49 & 367.12 \\
\hline $699-56-43$ & 540.42 & & 133.30 & 407.12 \\
\hline $699-57-29 B$ & 416.18 & & 54.99 & 361.19 \\
\hline $699-57-83$ & 578.22 & & 146.29 & 437.93 \\
\hline $699-58-24$ & 418.80 & & 57.71 & 361.09 \\
\hline $699-59-32$ & 424.29 & & 62.98 & 367.31 \\
\hline $699-59-58$ & 497.77 & & 95.54 & 402.23 \\
\hline $699-59-80 B$ & 583.25 & & 160.45 & 422.80 \\
\hline $699-60-32$ & 425.30 & & 64.05 & 361.25 \\
\hline $699-60-57$ & 496.64 & & 62.28 & 428.36 \\
\hline $699-60-60$ & 512.03 & & 111.70 & 400.33 \\
\hline $699-61-37$ & 442.94 & & 61.54 & 381.40 \\
\hline $699-61-41$ & 428.92 & & 33.23 & 395.69 \\
\hline $699-61-62$ & 497.51 & & 95.64 & 401.87 \\
\hline $699-61-66$ & 522.18 & & 121.26 & 400.92 \\
\hline $699-62-31$ & 434.12 & & 72.91 & 361.21 \\
\hline $699-62-43 A$ & 432.30 & & 36.40 & 395.90 \\
\hline $699-62-43 F$ & 423.34 & & 31.00 & 392.34 \\
\hline $699-63-25 A$ & 395.15 & & 34.13 & 361.02 \\
\hline $699-63-51$ & 424.54 & & 25.37 & 399.17 \\
\hline $699-63-58$ & 491.90 & & 91.36 & 400.54 \\
\hline $699-63-90$ & 509.73 & & 113.53 & 396.20 \\
\hline $699-63-92$ & 497.40 & & 100.39 & 397.01 \\
\hline $699-64-27$ & 414.29 & & 53.09 & 361.20 \\
\hline $699-64-62$ & 500.25 & & 100.03 & 400.22 \\
\hline $699-65-22$ & 391.10 & & 31.04 & 360.06 \\
\hline $699-65-38$ & 433.58 & & 32.51 & 401.07 \\
\hline $699-65-50$ & 467.06 & & 67.92 & 399.14 \\
\hline $699-65-59 A$ & .506 .96 & & 107.37 & 399.59 \\
\hline $699-65-72$ & 540.28 & & 142.40 & 397.88 \\
\hline
\end{tabular}


RHO-LD- 765

\begin{tabular}{|c|c|c|c|}
\hline Well & $\begin{array}{c}\text { Casing } \\
\text { elevation } \\
\text { (ft above } \\
\text { m.s.l.) }\end{array}$ & $\begin{array}{l}\text { Depth to } \\
\text { water } \\
(\mathrm{ft})\end{array}$ & $\begin{array}{c}\text { Water level } \\
\text { elevation } \\
\text { (ft above } \\
\text { m.s.l.) }\end{array}$ \\
\hline $699-65-83$ & 485.63 & 90.75 & 367.88 \\
\hline $699-65-95$ & 452.26 & 55.88 & 396.38 \\
\hline $699-66-23$ & 389.01 & 28.20 & 360.81 \\
\hline $699-66-38(0)$ & 436.46 & 33.50 & 402.96 \\
\hline $699=60-39$ & 453.70 & 47.97 & 406.73 \\
\hline $699-66-58$ & 503.33 & 105.96 & 397.37 \\
\hline $699-66-64$ & 505.92 & 106.39 & 399.53 \\
\hline $699-66-91$ & 467.15 & . 70.22 & 397.53 \\
\hline $699-66-103$ & 463.01 & 65.67 & 397.34 \\
\hline $699-67-51$ & 524.60 & 125.25 & 399.35 \\
\hline $699-67-86$ & 472.39 & 76.40 & 395.99 \\
\hline $699-67-98$ & 455.47 & 59.52 & 395.95 \\
\hline $699-68-105$ & 457.85 & 56.10 & 395.75 \\
\hline $699-69-38$ & 422.93 & 20.62 & 402.31 \\
\hline $699-69-4.5(n)$ & 487.18 & 88.48 & 398.70 \\
\hline $699-70-23$ & 391.71 & 29.56 & 362.15 \\
\hline $699-70-68$ & 526.22 & 127.93 & 398.29 \\
\hline $699-71-30$ & 400.68 & 29.70 & 370.98 \\
\hline $699-71-52$ & 523.00 & 124.50 & 398.50 \\
\hline $699-71-77$ & 472.28 & 77.25 & 395.03 \\
\hline $699-72-73$ & 482.57 & 86.75 & 395.82 \\
\hline $69 y-72-88$ & 437.37 & 39.04 & 398.33 \\
\hline $699-72-92(0)$ & 452.48 & 55.15 & 397.33 \\
\hline $699-74-44$ & 445.18 & 48.93 & 390.25 \\
\hline $693-74-48$ & 487.18 & 91.23 & $395.9 \overline{5}$ \\
\hline $699-73-61$ & 531.53 & 132.96 & 398.57 \\
\hline $699-77-36$ & 412.28 & 35.75 & 376.53 \\
\hline $699-77-54$ & 480.59 & 83.66 & 396.93 \\
\hline $699-78-62$ & 469.88 & 74.73 & 395.15 \\
\hline $699-80-43 S$ & 412.52 & 24.77 & 387.75 \\
\hline $699-81-38$ & 406.47 & 27.11 & 379.36 \\
\hline $699-81-58$ & 413.73 & 43.40 & 370.33 \\
\hline
\end{tabular}


RHO-LD-165

\begin{tabular}{|c|c|c|c|}
\hline Well & $\begin{array}{c}\text { Casing } \\
\text { elevation } \\
\text { (ft above } \\
\text { m.s.1.) }\end{array}$ & $\begin{array}{c}\text { Depth to } \\
\text { water } \\
(\mathrm{ft})\end{array}$ & $\begin{array}{c}\text { Water level } \\
\text { elevation } \\
\text { (ft above } \\
\text { m.s.l.) }\end{array}$ \\
\hline $699-82-45 A$ & 413.73 & 26.10 & 387.63 \\
\hline $699-83-32$ & 407.58 & 38.07 & 369.51 \\
\hline $699-83-47$ & 435.27 & 46.44 & 388.83 \\
\hline $699-84-35 A$ & 400.05 & 25.90 & 374.15 \\
\hline $699-86-42$ & 409.92 & 25.33 & 384.59 \\
\hline $699-87-55$ & 458.63 & 70.55 & 388.08 \\
\hline $699-89-35$ & 397.46 & 26.90 & 370.56 \\
\hline $699-90-34$ & 392.39 & 22.21 & 390.18 \\
\hline $699-90-45$ & 422.15 & 37.50 & 384.65 \\
\hline $699-91-37$ & 422.93 & 50.56 & 372.37 \\
\hline $699-92-49$ & 432.09 & 49.06 & 383.03 \\
\hline $699-97-43$ & 421.81 & 43.12 & 378.69 \\
\hline $699-99-42^{b}$ & 412.88 & & \\
\hline 299-E13-3 & .741 .48 & 338.52 & 402.91 \\
\hline 299-E13-10 & 733.75 & 333.19 & 400.56 \\
\hline 299-E $13-12$ & 731.34 & 330.24 & 401.10 \\
\hline 299-E13-14 & 742.85 & 339.66 & 403.19 \\
\hline $299-E 16-2^{9}$ & 680.56 & & \\
\hline 299-E17-1 & 718.88 & 316.61 & 402.27 \\
\hline 299-E19-1 & 736.00 & 332.48 & 403.52 \\
\hline 299-E23-1 & 709.65 & 307.02 & 402.63 \\
\hline $299-E 23-2(0)$ & 721.00 & $318: 60$ & 402.40 \\
\hline 299-E24-4 & 697.00 & 294.32 & 402.68 \\
\hline 299-E24-7 & 716.32 & 313.67 & 402.65 \\
\hline 299-E25-3 & 691.81 & 289.13 & 402.05 \\
\hline 299-E25-4 & 659.39 & 255.24 & 404.15 \\
\hline 299-E25-9 & 655.16 & 252.17 & 402.99 \\
\hline $299-E 25-11^{g}$ & 681.51 & & \\
\hline 299-E26-1 & 617.25 & 274.40 & 402.85 \\
\hline 299-E26-4 & 645.50 & 242.47 & 403.03 \\
\hline 299-E27-1 & 681.05 & 278.29 & 402.76 \\
\hline $299-E 27-3(0)$ & 683.53 & 280.85 & 402.68 \\
\hline
\end{tabular}


RHO-LD-165

\begin{tabular}{|c|c|c|c|}
\hline Well & $\begin{array}{c}\text { Casing } \\
\text { elevation } \\
\text { (ft above } \\
\text { m.s.l.) }\end{array}$ & $\begin{array}{l}\text { Depth to } \\
\text { water } \\
(\mathrm{ft})\end{array}$ & $\begin{array}{c}\text { Water level } \\
\text { elevation } \\
\text { (ft above } \\
\text { m.s.1.) }\end{array}$ \\
\hline 299-E28-7 & 685.91 & 284.09 & 401.82 \\
\hline 299-E28-8 & 668.58 & 265.98 & 402.60 \\
\hline 299-E28-18 & 692.58 & 289.98 & 402.60 \\
\hline 299-E32-1 & 656.17 & 253.67 & 402.50 \\
\hline 299-E33-7 & $625.99+0.55^{h}$ & 224.34 & 402.20 \\
\hline 299-E33-8 & 648.04 & 245.43 & 402.61 \\
\hline $299-E 33=12$ & 623.60 & 219.58 & 404.02 \\
\hline $299-F .33-14$ & 622.12 & 219.48 & 402.64 \\
\hline $299-E 33-17$ & 631.66 & 229.10 & 402.56 \\
\hline 299-E33-21 & 663.43 & 260.87 & 402.50 \\
\hline 299-E34-1 & 629.42 & 226.80 & $4 \cap ? .62$ \\
\hline 299-W10-2 & 674.33 & 204.67 & 469.66 \\
\hline 299-W10-5 & 672.31 & 201.14 & 471.17 \\
\hline 299-W10-8 & 680.33 & 211.90 & 468.43 \\
\hline 299-Wา1-2(0) & 714.74 & 249.68 & 465.06 \\
\hline $299-W 11-7$ & 709.11 & 242.22 & 466.89 \\
\hline 299-W1 T-9 & 722.94 & 261.18 & 461.76 \\
\hline $299-W 11-10$ & 738.89 & 270.04 & 458.85 \\
\hline 299-W11-12 & 679.58 & 210.44 & 469.11 \\
\hline 299-Wา1-13(0) & 692.27 & 223.15 & 469.12 \\
\hline $299-W 11-23$ & 686.12 & 217.71 & 468.41 \\
\hline 299-W12-1 & 726.16 & 273.33 & 453.13 \\
\hline $299-w 14-1^{i}$ & 665.83 & & \\
\hline 299-W15-2 & 690.71 & 217.80 & 472,91 \\
\hline $299-W 75-4$ & 662.00 & 187.02 & 474.98 \\
\hline $299-W 15-5(0)$ & 670.95 & 193.44 & 477.51 \\
\hline 299-W19-1 (0) & 674.04 & 193.56 & 480.48 \\
\hline $299-W 19-3$ & 695.12 & 221.86 & 473.26 \\
\hline 299-W79-4 & 715.52 & 251.02 & 464.50 \\
\hline $299-W 21-1$ & 699.26 & 239.08 & 460.18 \\
\hline 299-W22-7 & 687.41 & 220.67 & 466.74 \\
\hline $299-w 22-17$ & $672.00+0.10^{h}$ & 197.70 & 474.40 \\
\hline
\end{tabular}


RHO-LD-165

\begin{tabular}{l|c|c|c}
\hline We11 & $\begin{array}{c}\text { Casing } \\
\text { elevation } \\
\text { (ft above } \\
\text { m.S.1.) }\end{array}$ & $\begin{array}{c}\text { Depth to } \\
\text { water } \\
(\mathrm{ft})\end{array}$ & $\begin{array}{c}\text { Water level } \\
\text { elevation } \\
\text { (ft above } \\
\text { m.s.1.) }\end{array}$ \\
\hline 299-W22-22 & 690.38 & 224.44 & 465.94 \\
299-W22-33 & $675.00+0.38^{h}$ & 204.82 & 470.56 \\
299-W22-35 & $681.00+0.07^{h}$ & 204.85 & 476.22 \\
299-W23-4 & 662.82 & 182.14 & 480.68 \\
$299-W 23-11$ & 664.14 & 185.59 & 478.55 \\
199-B4-1 & 461.70 & 64.74 & 396.96 \\
$199-D 2-5$ & 460.86 & 73.63 & 387.23 \\
199-F5-1 & 406.56 & 36.74 & 369.82 \\
199-H3-1 & 421.98 & 45.78 & 376.20 \\
199-K-11 & 467.00 & 74.36 & 392.64 \\
$399-8-1$ & 394.87 & 52.08 & 342.79 \\
\hline
\end{tabular}

$a_{\text {The flowing zone is confined. }}$

bory.

obstructed.

dobstruction at 221 feet.

$e_{\text {Wet. }}$

fould not locate.

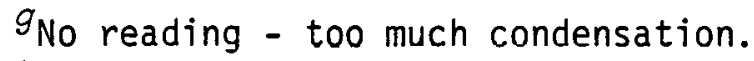

${ }^{h}$ Casing elevations need these official corrections.

$i_{\text {Dry }}$ or obstructed. 
RHO-LD-165

APPENDIX D

ROCKWELL GROUND-WATER MONITORING NETWORK - 1980 RESULTS 


\begin{tabular}{|c|c|c|c|c|c|c|c|c|c|c|}
\hline Well number & $\begin{array}{c}\text { Site } \\
\text { monitared }\end{array}$ & $\begin{array}{c}\text { Total alpha } \\
(p<i / m L)\end{array}$ & $\begin{array}{l}\text { Tatal beta } \\
(\mathrm{pCj} / \mathrm{mL})\end{array}$ & $\begin{array}{c}3_{H}^{H} \\
(p C 1 / m L)\end{array}$ & $\begin{array}{c}90_{S r} \\
(p C i / m L)\end{array}$ & $\begin{array}{c}{ }^{137} \mathrm{cs} \\
(p C \mathrm{i} / \mathrm{mL})\end{array}$ & $\begin{array}{c}{ }^{106} \mathrm{Ru}_{\mathrm{Ru}} \\
(\mathrm{pCi} / \mathrm{mL})\end{array}$ & $\begin{array}{c}{ }^{60} \mathrm{Co} \\
(\mathrm{pC} \mathrm{i} / \mathrm{mL})\end{array}$ & $\begin{array}{c}\mathrm{NO}_{3}^{-} \\
(\mathrm{p} / \mathrm{m})\end{array}$ & $\begin{array}{c}U \\
(m g / L)\end{array}$ \\
\hline \multicolumn{2}{|c|}{ Table II Limits } & $\mathrm{NA}^{a}$ & $N A^{a}$ & $3.00 E+03$ & $3.00 E-01$ & $2.00 E+01$ & $1.00 E+01$ & $3.00 E+01$ & $4.5 E+01$ & \\
\hline $\begin{array}{l}2 E-13-5 \\
\text { Maxinum } \\
\text { Mean } \\
\text { Minimum }\end{array}$ & $216-8-18$ & & $<7.5 \mathrm{CE}-02^{b}$ & $<5.50 E-01$ & & & & & & \\
\hline $\begin{array}{l}\text { 2E-13-8 } \\
\text { Maximum } \\
\text { Mean } \\
\text { Minimum }\end{array}$ & $216-8-21$ & & $<7.5 \mathrm{GE}-02^{b}$ & & & & & & & \\
\hline $\begin{array}{l}2 \mathrm{E}-13-14 \\
\text { Maximum } \\
\text { Mean } \\
\text { Minimum }\end{array}$ & $216-8-29$ & & $\begin{array}{l}<7.50 \mathrm{E}-02 \\
<5.6 \mathrm{gE}-02 \\
<2.24 \mathrm{E}-03\end{array}$ & & & & & & & \\
\hline $\begin{array}{c}2 E-13-19 \\
\text { raximum } \\
\text { Mean } \\
\text { Mininum }\end{array}$ & $216-B-28$ & & $<7.50 \mathrm{E}-02^{b}$ & & & & & & & \\
\hline $\begin{array}{l}2 E-13-20 \\
\text { Maximum } \\
\text { Mean } \\
\text { Minimum }\end{array}$ & B-C cribs & & $<4.21 \mathrm{E}-02^{b}$ & & & & & & & \\
\hline $\begin{array}{l}2 E-15-1 \\
\text { Maximum } \\
\text { Mean } \\
\text { Minimum }\end{array}$ & $216-A-30$ & & $\begin{array}{l}<7.50 E-02 \\
<5.99 E-02 \\
<1.46 E-02\end{array}$ & & & . & & & & \\
\hline $\begin{array}{l}\text { 2E-16-2 } \\
\text { Maximuin } \\
\text { Mean } \\
\text { Minimuin }\end{array}$ & $216-A-30$ & & $\begin{array}{l}<7.50 \mathrm{E}-02 \\
<4.70 \mathrm{E}-02 \\
<3.53 \mathrm{E}-03\end{array}$ & & & & & & & \\
\hline $\begin{array}{l}\text { 2E-17-1 } \\
\text { Maximum } \\
\text { Mean } \\
\text { Minimum }\end{array}$ & $216-A-10$ & & $\begin{array}{l}7.90 \mathrm{E}-02 \\
7.02 \mathrm{E}-02 \\
5.18 \mathrm{E}-02\end{array}$ & & $7.33 \mathrm{E}-03^{b}$ & & & & $6.80 \mathrm{E}+00^{b}$ & \\
\hline
\end{tabular}




\begin{tabular}{|c|c|c|c|c|c|c|c|c|c|c|}
\hline Well number & $\begin{array}{c}\text { Site } \\
\text { nonitored }\end{array}$ & $\begin{array}{c}\text { TCtal alpha } \\
(\mathrm{pCi} / \mathrm{mL})\end{array}$ & $\begin{array}{l}\text { Tctal beta } \\
(\rho \subset i / m L)\end{array}$ & $\begin{array}{c}3_{H}^{H} \\
(p C i / / n L)\end{array}$ & $\begin{array}{c}{ }^{9 C} \mathrm{Sr} \\
(p C 1 / \mathrm{mL})\end{array}$ & $\begin{array}{c}{ }^{137} \mathrm{Cs} \\
(\mathrm{pCi} / \mathrm{mL})\end{array}$ & ${ }_{(\mathrm{pCi}, \mathrm{imL})}^{10 \bar{b}_{\mathrm{Ru}}}$ & $\stackrel{{ }^{60} \mathrm{Co}}{(p C 1 / \mathrm{mL})}$ & $\begin{array}{c}N 0_{3}^{-} \\
\left(p / m^{\prime}\right)\end{array}$ & $\underset{(m g / L)}{U}$ \\
\hline \multicolumn{2}{|c|}{ Table II Limits } & $\mathrm{NA}^{a}$ & $\mathrm{NA}^{a}$ & $3.00 E-03$ & $3.0 \mathrm{CE}-01$ & $2.00 E+01$ & $1.00 E+01$ & $3.00 E+01$ & $4.5 E+01$ & \\
\hline $\begin{array}{l}2 E-17-2 \\
\text { Maximum } \\
\text { Mean } \\
\text { Minimum }\end{array}$ & $216-A-27$ & $\begin{array}{l}\text { A. } 40 \equiv-02 \\
\text { 3. } 33 \equiv-02 \\
\text { C. } 60=-02\end{array}$ & $\begin{array}{r}<7.50 \mathrm{E}-02 \\
<7.20 \mathrm{E}-02 \\
5.58 \mathrm{E}-02\end{array}$ & & & & & & 7. $30 \mathrm{E}+00^{b}$ & $\begin{array}{l}2.20 \mathrm{E}-02 \\
1.71 \mathrm{E}-02 \\
1.40 \mathrm{E}-02\end{array}$ \\
\hline $\begin{array}{l}2 E-17-5 \\
\quad \text { Maximum } \\
\text { Mean } \\
\text { Minimum }\end{array}$ & $216-A-36 B$ & $<\mathrm{T} .70 \mathrm{E}-02^{b}$ & $\begin{array}{l}1.37 E-01 \\
7.82 E-02 \\
2.91 E-02\end{array}$ & 3. $70 \equiv-02^{b}$ & 5.03E $-03^{b}$ & $1.61 \mathrm{E}-02^{b}$ & & $2.76 \mathrm{E}-02^{b}$ & $3.20 \mathrm{E}+01^{b}$ & \\
\hline $\begin{array}{l}2 E-17-6 \\
\quad \text { Maximum } \\
\text { Mean } \\
\text { Minimum }\end{array}$ & 2.16-A-36 & & $\begin{array}{l}<7.50 \mathrm{E}-02 \\
<5.29 \mathrm{E}-02 \\
<1.17 \mathrm{E}-02\end{array}$ & & & & & & & \\
\hline $\begin{array}{l}2 \mathrm{E}-17-8 \\
\text { Maximum } \\
\text { Mean } \\
\text { Minimum }\end{array}$ & c16-A-38 & & $\begin{array}{r}<7.50 \mathrm{E}-02 \\
<6.63 \mathrm{E}-02 \\
4.89 \mathrm{E}-02\end{array}$ & & & & & & & \\
\hline $\begin{array}{l}\text { 2E-17-9 } \\
\quad \text { Maximun } \\
\text { Mean } \\
\text { Mininumi }\end{array}$ & $276-A-36 B$ & $<1.70 \mathrm{E}-02^{b}$ & $\begin{array}{r}<7.50 \mathrm{E}-02 \\
<6.75 \mathrm{E}-02 \\
4.64 \mathrm{E}-02\end{array}$ & $1.80 \mathrm{E}-0 \mathrm{I}^{b}$ & $3.87 E-03^{b}$ & $1.11 \mathrm{E}-02^{b}$ & & $1.95 \mathrm{E}-02^{b}$ & $1.92 E+02^{b}$ & \\
\hline $\begin{array}{l}\text { E-23-2 } \\
\quad \text { Maximuin } \\
\text { Mean } \\
\text { Mininum }\end{array}$ & $200 E$ & & $6.80 E-02^{b}$ & $3.70 \varepsilon+00^{b}$ & & & & & $6.05 \mathrm{E}+00^{b}$ & \\
\hline $\begin{array}{l}\text { E-24-1 } \\
\text { Maxinum } \\
\text { Mean } \\
\text { Minimum }\end{array}$ & $276-A-5$ & $\cdot$ & $<5.76 \mathrm{E}-02^{b}$ & $4.70 E+32^{b}$ & $2.70 \mathrm{E}-03^{b}$ & & & & & \\
\hline $\begin{array}{l}\text { E-24-2 } \\
\quad \text { Maximun } \\
\text { Mean } \\
\text { Mininum }\end{array}$ & $2116-A-10$ & $<1.70 E-02^{b}$ & $\begin{array}{r}<7.50 \mathrm{E}-02 \\
<6.93 \mathrm{E}-02 \\
5.20 \mathrm{E}-02\end{array}$ & 5. $53 E+1] 2^{b}$ & & $3.00 E-03$ & & $2.80 E-02$ & & $2.72 \mathrm{E}-03^{b}$ \\
\hline $\begin{array}{l}\text { E-24-4 } \\
\text { Maxinnun } \\
\text { Mean } \\
\text { Minimunn }\end{array}$ & 216-A-9 & . & $\begin{array}{l}<7.50 \mathrm{E}-02 \\
<5.20 \mathrm{E}-02 \\
<2.90 \mathrm{E}-02\end{array}$ & & & & & & & \\
\hline
\end{tabular}




\begin{tabular}{|c|c|c|c|c|c|c|c|c|c|c|}
\hline Well number & $\begin{array}{c}\text { Site } \\
\text { moni tored }\end{array}$ & $\begin{array}{c}\text { Total alpha } \\
\text { (pCi/mL) }\end{array}$ & $\begin{array}{l}\text { Total beta } \\
(\mathrm{pCl} / \mathrm{mL})\end{array}$ & $\left.\begin{array}{c}3_{H}^{H} \\
(p C i / m L\end{array}\right)$ & $\begin{array}{c}90 \\
(\mathrm{pC} \dot{S} / \mathrm{mL})\end{array}$ & $\begin{array}{l}{ }^{137} \mathrm{Cs} \\
(p \mathrm{i} / \mathrm{mL})\end{array}$ & $\begin{array}{c}106_{R U} \\
(p C 1 / m L)\end{array}$ & $\begin{array}{c}{ }^{60} \mathrm{co} \\
(p C i / m L)\end{array}$ & $\begin{array}{l}\mathrm{NO}_{3}^{-} \\
(\mathrm{p} / \mathrm{m})\end{array}$ & $\underset{(m g / L)}{U}$ \\
\hline \multicolumn{2}{|c|}{ Table 11 Lianits } & $\mathrm{NA}^{a}$ & $M A^{a}$ & $3.00 E+03$ & $3.00 E-01$ & $2.0 \mathrm{CE}+01$ & $1.00 E+01$ & $3.00 \mathrm{E}+01$ & $4.5 E+01$ & \\
\hline $\begin{array}{l}\text { E-24-8 } \\
\text { Maximum } \\
\text { Mean } \\
\text { Minimum }\end{array}$ & $216-C-5$ & & $<4.70 \mathrm{E}-02^{b}$ & $2.45 \mathrm{E}+01^{b}$ & & $1.8 \mathrm{CE}-03^{b}$ & & $<1.47 E+02^{b}$ & $2.10 E+00^{b}$ & \\
\hline $\begin{array}{l}\text { E-24-12 } \\
\text { Maximum } \\
\text { Mean } \\
\text { Minimum }\end{array}$ & $216-A-31$ & $4.63 \mathrm{E}-02^{b}$ & $\begin{array}{r}3.20 \mathrm{E}-0\} \\
1.43 \mathrm{E}-01 \\
<7.50 \mathrm{E}-02\end{array}$ & & & & & & & $3.25 \mathrm{E}-02^{b}$ \\
\hline $\begin{array}{l}\text { E-24-13 } \\
\text { Maximum } \\
\text { Mean } \\
\text { Minimum }\end{array}$ & 241-A-TF & & $8.75 \mathrm{E}-02^{b}$ & & & & & & & \\
\hline $\begin{array}{l}\text { E-25-3 } \\
\text { Maximum } \\
\text { Mean } \\
\text { Minimum }\end{array}$ & $216-A-6$ & . & $<7.50 E-02$ & & & & & & & \\
\hline $\begin{array}{l}\text { E-25-6 } \\
\text { Maximum } \\
\text { Mean } \\
\text { Minimum }\end{array}$ & $216-A-8$ & & $\begin{array}{l}<7.50 \mathrm{E}-02 \\
<6.90 \mathrm{E}-02 \\
<2.09 \mathrm{E}-02\end{array}$ & $\begin{array}{l}7.20 E+02 \\
5.18 E+02 \\
1.20 E+01\end{array}$ & & $1.65 \mathrm{E}-02^{b}$ & & $\begin{array}{r}4.70 \mathrm{E}-02 \\
2.57 \mathrm{E}-02 \\
<1.02 \mathrm{E}-02\end{array}$ & & \\
\hline $\begin{array}{l}\text { E-25-9 } \\
\text { Maximum } \\
\text { Mean } \\
\text { Minimum }\end{array}$ & $216-A-8$ & & $\begin{array}{l}<7.50 \mathrm{E}-02 \\
<5.65 \mathrm{E}-02 \\
<9.4 \geq \mathrm{E}-04\end{array}$ & & & & & & 8. $50 \mathrm{E}+00^{b}$ & \\
\hline $\begin{array}{l}\text { E-25-10 } \\
\text { Maximum } \\
\text { Mean: } \\
\text { Minimum }\end{array}$ & & $<1.70 \mathrm{E}-02^{b}$ & $<7.50 \mathrm{E}-02^{b}$ & & & & & & . & $<6.90 \mathrm{E}-03^{b}$ \\
\hline $\begin{array}{l}\text { E-25-11 } \\
\text { Maximum } \\
\text { Mean } \\
\text { Minimum }\end{array}$ & $216-A-30$ & & $<.50 \mathrm{E}-02^{b}$ & & & & & & & \\
\hline $\begin{array}{l}\text { E-25-13 } \\
\text { Maximum } \\
\text { Mean } \\
\text { Minimum }\end{array}$ & 216-AX-TF & & $<7.50 \mathrm{E}-02^{b}$ & & & & & & & \\
\hline
\end{tabular}




\begin{tabular}{|c|c|c|c|c|c|c|c|c|c|c|}
\hline Well number & $\begin{array}{c}\text { Sitz } \\
\text { monito-ed }\end{array}$ & $\begin{array}{c}\text { Total alphia } \\
\text { (pCi/mL) }\end{array}$ & $\begin{array}{c}\text { Total beta } \\
\text { (pCi/mL) }\end{array}$ & $\begin{array}{c}3_{H}^{H} \\
(\mathrm{pCi} / \mathrm{nn}:)\end{array}$ & $\begin{array}{c}{ }^{910} \mathrm{Sr} \\
(\mathrm{pCl} / \mathrm{mL})\end{array}$ & $\begin{array}{c}{ }^{137} \mathrm{Cs} \\
(\mathrm{pCt} / \mathrm{ml})\end{array}$ & $\begin{array}{c}1 C \sigma_{R u} \\
(p C i / w L)\end{array}$ & $\left.{ }_{(p C i / m L}^{60} C_{0}\right)$ & $\begin{array}{l}\mathrm{NO}_{3}^{-} \\
(\mathrm{p} / \mathrm{m})\end{array}$ & $\underset{(m g / L)}{U}$ \\
\hline \multicolumn{2}{|c|}{ Table 11 Limits } & $A A^{a}$ & $N A^{a}$ & $\Xi .00 E+03$ & $3.00 \mathrm{E}-01$ & $2.00 E+01$ & $1.00 \mathrm{E}+01$ & $3.00 E+01$ & $4.5 E+01$ & \\
\hline $\begin{array}{l}\text { E-25-17 } \\
\text { Maximum } \\
\text { Mean } \\
\text { Minimum }\end{array}$ & $216-A-37$ & & $3.09 \mathrm{E}-02^{b}$ & $11.64 E+02^{b}$ & & & & & & \\
\hline $\begin{array}{l}E-25-18 \\
\text { Maximum } \\
\text { Mean } \\
\text { Minimum }\end{array}$ & $216-A-37$ & & $1.61 E-02^{b}$ & a. $53 \mathrm{E}+02^{b}$ & & & & & & \\
\hline $\begin{array}{l}\text { E-25-19 } \\
\text { Maximum } \\
\text { Mean } \\
\text { Minimum }\end{array}$ & $216-A-37$ & & $2.49 \mathrm{E}-02^{b}$ & 9. $96 \mathrm{E}+\left[\cdot 2^{b}\right.$ & & & & & & \\
\hline $\begin{array}{l}\text { E-25-20 } \\
\text { Maximulu } \\
\text { Mean } \\
\text { Minimum }\end{array}$ & $? 16-A-\because 7$ & & $<4.73 \mathrm{E}-03^{b}$ & $5.81 E+02^{b}$ & & & & & & \\
\hline $\begin{array}{l}\text { E-26-2 } \\
\text { Maximum } \\
\text { Mean } \\
\text { Minimum }\end{array}$ & $216-A-c 4$ & & $<7.50 E-02^{b}$ & & & & & & & \\
\hline $\begin{array}{l}\text { E-26-4 } \\
\text { Maximuul } \\
\text { Mean } \\
\text { Mininuun }\end{array}$ & $216-A-z 4$ & & $<7.50 \mathrm{E}-02^{L}$ & $6.03 E+0.7^{b}$ & & & & & & \\
\hline $\begin{array}{l}\text { E-27-5 } \\
\text { Maximum } \\
\text { Mean } \\
\text { Minimum }\end{array}$ & $216-C-10$ & & $\begin{array}{l}<7.50 \mathrm{E}-02 \\
<5.91 \mathrm{E}-02 \\
<1.15 \mathrm{E}-02\end{array}$ & & & $2.85 \mathrm{E}-03^{b}$ & & $<1.50 \mathrm{E}-02^{b}$ & & \\
\hline $\begin{array}{l}\text { E-28-12 } \\
\text { Maxinum } \\
\text { Mean } \\
\text { Minimum }\end{array}$ & $=16-8-55$ & & $\begin{array}{r} \\
<? .50 \mathrm{E}-02 \\
<7.06 \mathrm{E}-02 \\
3.06 \mathrm{E}-02\end{array}$ & $\begin{array}{l}1.40 E+0 ? \\
1.13 E+02 \\
9.30 E+01\end{array}$ & & $<6.52 \mathrm{E}-04^{b}$ & & $<2.87 \mathrm{E}-02^{b}$ & & \\
\hline $\begin{array}{l}\text { E-28-13 } \\
\text { Maximum } \\
\text { Mean } \\
\text { Minimum }\end{array}$ & $216-B-5 j$ & & & & & $2.24 E-03^{b}$ & & $<1.20 \mathrm{E}-02^{b}$ & & \\
\hline
\end{tabular}




\begin{tabular}{|c|c|c|c|c|c|c|c|c|c|c|}
\hline Well number & $\begin{array}{c}\text { Site } \\
\text { monitored }\end{array}$ & $\begin{array}{c}\text { Totál a lpha } \\
\text { (pCi/mL) }\end{array}$ & $\begin{array}{l}\text { Total beta } \\
\text { (pCi/mL) }\end{array}$ & $\begin{array}{c}3_{H}^{H} \\
(p C i / m L)\end{array}$ & $\begin{array}{c}90 \mathrm{Sr} \\
(\mathrm{pC} 1 / \mathrm{mL})\end{array}$ & $\begin{array}{c}137 \mathrm{Cs} \\
(\mathrm{pC1} 1 / \mathrm{mL})\end{array}$ & $\begin{array}{c}106 \\
R u \\
(p C i / m L)\end{array}$ & $\begin{array}{c}{ }^{60} \mathrm{Co} \\
(\mathrm{pCi} / \mathrm{mL})\end{array}$ & $\stackrel{\mathrm{NO}_{3}^{-}}{(\mathrm{p} / \mathrm{m})}$ & $\underset{(m g / L)}{U}$ \\
\hline \multicolumn{2}{|c|}{ Table II Limits } & $\mathrm{NA}^{a}$ & $M A^{a}$ & $3.00 E+03$ & 3.00E-01 & $2.00 E+01$ & $1.00 E+01$ & $3.00 E+01$. & $4.5 E+01$ & \\
\hline $\begin{array}{l}\text { E-28-16 } \\
\text { Maxinum } \\
\text { Mean } \\
\text { Minimum }\end{array}$ & $216-B-12$ & & $<7.50 \mathrm{E}-02$ & & & & & . & & \\
\hline $\begin{array}{l}E-28-17 \\
\text { Maximum }\end{array}$ & $\begin{array}{c}216-B- \\
10 A, B\end{array}$ & & & & & & & & & \\
\hline $\begin{array}{l}\text { Mean } \\
\text { Mininum }\end{array}$ & & $2.43 \mathrm{E}-02^{b}$ & & & & & & & & $1.23 \mathrm{E}-02^{b}$ \\
\hline $\begin{array}{l}\text { E-28-18 } \\
\text { Maximum } \\
\text { Mean } \\
\text { Minimum }\end{array}$ & $216-8-62$ & & $\begin{array}{r}8.80 E-02 \\
7.96 C E-02 \\
7.5 C E-02\end{array}$ & & $2.90 \mathrm{E}-03^{b}$ & 1.09E-02 & & $2.03 \mathrm{E}-02^{b}$ & & \\
\hline $\begin{array}{l}\text { 2E-28-21 } \\
\text { Maximum } \\
\text { Mean } \\
\text { Minfmum }\end{array}$ & $216-B-62$ & & $\begin{array}{r}<7.5 \mathrm{CE}-02 \\
<7.36 \mathrm{GE}-02 \\
6.07 \mathrm{E}-02\end{array}$ & & $<2.07 \mathrm{E}-03^{b}$ & $4.48 \mathrm{E}-02^{b}$ & & $3.25 \mathrm{E}-02^{b}$ & & \\
\hline $\begin{array}{l}2 E-32-1 \\
\text { Maximum } \\
\text { Mean } \\
\text { Minimum! }\end{array}$ & $200 E$ & & $5.91 \mathrm{E}-02^{b}$ & $2.99 \mathrm{E}+01^{b}$ & & & & & $9.00 \mathrm{E}+01^{b}$ & \\
\hline $\begin{array}{l}\text { 2E-33-1 } \\
\text { Maximum } \\
\text { Mean } \\
\text { Minimun }\end{array}$ & $216-8-43$ & & $\begin{array}{l}3.20 \mathrm{E}-01 \\
2.38 \mathrm{E}-01 \\
1.30 \mathrm{E}-01\end{array}$ & & $\begin{array}{l}2.20 \mathrm{E}-02 \\
5.77 \mathrm{E}-03 \\
9.91 \mathrm{E}-04\end{array}$ & $2.79 E-02^{b}$ & & $\begin{array}{l}1.20 \mathrm{E}-01 \\
6.32 \mathrm{E}-02 \\
1.20 \mathrm{E}-02\end{array}$ & & \\
\hline$E-33-3$ & $\begin{array}{c}216-8-74, \\
45,76\end{array}$ & & & & & & & & & \\
\hline $\begin{array}{l}\text { Maximuln } \\
\text { Mean } \\
\text { Minimun }\end{array}$ & & & $1.40 \equiv+00$ & $5.80 E+01$ & 3. $30 \mathrm{E}-03^{b}$ & & & $1.50 \mathrm{E}+00^{b}$ & & \\
\hline $\begin{array}{l}2 E-33-5 \\
\text { Maximum } \\
\text { Maan } \\
\text { Minimum }\end{array}$ & $216-8-47$ & & $<8.00 \mathrm{E}-01^{b}$ & & & & & $2.80 \mathrm{E}-01^{b}$ & & \\
\hline
\end{tabular}




\begin{tabular}{|c|c|c|c|c|c|c|c|c|c|c|}
\hline Well number & $\begin{array}{c}\text { Site } \\
\text { monitored }\end{array}$ & $\begin{array}{l}\text { T.Jtal alpha . } \\
(p(\mathrm{i} / \mathrm{mL})\end{array}$ & $\begin{array}{l}\text { Total beta } \\
(\mathrm{pCi} / \mathrm{mL})\end{array}$ & $\begin{array}{c}3_{\mathrm{H}} \\
(\mathrm{pC} / \mathrm{mL})\end{array}$ & $\begin{array}{c}{ }^{90} \mathrm{Sr} \\
\mathrm{(PCl} / \mathrm{mL})\end{array}$ & $\begin{array}{l}137 \mathrm{Cs} \\
(\rho \mathrm{Ci} / \mathrm{mL})\end{array}$ & $\begin{array}{c}106_{\mathrm{Ru}} \\
(\mathrm{pCi} / \mathrm{inL})\end{array}$ & $\begin{array}{c}{ }^{60} \mathrm{Co} \\
(p C i / m L)\end{array}$ & $\begin{array}{l}\mathrm{NO}_{3}^{-} \\
(\mathrm{p} / \mathrm{m})\end{array}$ & $\underset{(m g / L)}{U}$ \\
\hline \multicolumn{2}{|c|}{ Table II Limits } & $A A^{a}$ & $\mathrm{NA}^{a}$ & $\Xi .00 E+03$ & $3.00 E-01$ & $2.00 E+(1)$ & $1.00 \mathbf{E}+01$ & $3.00 E+01$ & $4.5 E+01$ & \\
\hline $\begin{array}{l}2 E-33-7 \\
\text { Maximull } \\
\text { Mean } \\
\text { Minimum } \\
2 E-33-8 \\
\text { Maximum } \\
\text { Mean } \\
\text { Minimual }\end{array}$ & $\begin{array}{c}216-8-48 \\
49,50\end{array}$ & & $2.70 E+00^{b}$ & & & & & $\begin{array}{l}1.30 \mathrm{E}+00^{b} \\
3.80 \mathrm{E}-02^{b}\end{array}$ & & \\
\hline $\begin{array}{l}\text { 2E-33-9 } \\
\text { Maximum } \\
\text { Mean } \\
\text { Minimum }\end{array}$ & $241-8 Y-\mathrm{JF}$ & & $\begin{array}{l}1.01 E-01 \\
2.66 E-01 \\
2.00 E-01\end{array}$ & & $\begin{array}{l}0.40 E-03 \\
3.71 E-03 \\
9.01 E-04\end{array}$ & $\begin{array}{r}3.30 \mathrm{E}-\mathrm{C} 2 \\
2.54 \mathrm{E}-\mathrm{C} 2 \\
<1.27 \mathrm{E}-\mathrm{C} 2\end{array}$ & & $2.05 \mathrm{E}-02^{b}$ & & $\begin{array}{l}4.30 E+02 \\
2.76 E+02 \\
1.40 E+02\end{array}$ \\
\hline $\begin{array}{l}\text { E-33-10 } \\
\text { Maximum } \\
\text { Mean } \\
\text { Minimun }\end{array}$ & $216-8-35$ & & $<? .50 \mathrm{E}-02^{b}$ & $9.23 \mathrm{E}-01^{b}$ & & & & & $2.97 E+01$ & \\
\hline $2 E-33-18$ & $\frac{216-B-7 A}{B}$ & & & & & & & & & \\
\hline $\begin{array}{l}\text { Maximum } \\
\text { Mean } \\
\text { Minimumum }\end{array}$ & & & $\begin{array}{l}8.70 \mathrm{E}-02 \\
7.32 \mathrm{E}-02 \\
5.20 \mathrm{E}-02\end{array}$ & & $\begin{array}{r}6.70 E-03 \\
2.73 E-03 \\
<2.70 E-03\end{array}$ & $1.45 \mathrm{E}-\mathrm{C} 3^{b}$ & & $<2.72 \mathrm{E}-02^{b}$ & & \\
\hline $\begin{array}{l}\text { 2E-33-20 } \\
\text { Maximum } \\
\text { Mean } \\
\text { Mininum }\end{array}$ & $\begin{array}{c}216-B-7 A, \\
B, \| A, \\
B\end{array}$ & $<\bar{i} .70 \mathrm{E}-02^{b}$ & & & & & & & & \\
\hline $\begin{array}{l}\text { 2E-33-21 } \\
\text { Maximuml } \\
\text { Mean } \\
\text { Minimum }\end{array}$ & $216-8-36$ & & $<\mathrm{i} .50 \mathrm{E}-02^{b}$ & & & & & $1.90 \mathrm{E}-02^{b}$ & . & \\
\hline $\begin{array}{l}\text { 2E-33-24 } \\
\text { Maximum } \\
\text { Mean } \\
\text { Minimum }\end{array}$ & $216-8-5$ & & $\begin{array}{r}6.00 \mathrm{E}-01 \\
3.66 \mathrm{E}-01 \\
<.50 \mathrm{E}-02\end{array}$ & & & $2.24 \mathrm{E}-00^{b}$ & & $\begin{array}{l}7.10 \mathrm{E}-01 \\
2.22 \mathrm{E}-01 \\
1.40 \mathrm{E}-02\end{array}$ & & \\
\hline
\end{tabular}




\begin{tabular}{|c|c|c|c|c|c|c|c|c|c|c|}
\hline Well number & $\begin{array}{c}\text { Si te } \\
\text { manitored }\end{array}$ & $\begin{array}{c}\text { Total alpha } \\
(p C i / m L)\end{array}$ & $\begin{array}{l}\text { Total beta } \\
\text { (pCi/mL) }\end{array}$ & $\begin{array}{c}3_{H} \\
(p C i / m L)\end{array}$ & $\begin{array}{c}90 \mathrm{Sr} \\
(\mathrm{pC} 1 / \mathrm{mL})\end{array}$ & $\begin{array}{l}{ }^{137} \mathrm{Cs} \\
(\mathrm{pCi} / \mathrm{mL})\end{array}$ & $\begin{array}{c}{ }^{106}{ }_{R u} \\
(p C i / m L)\end{array}$ & $\begin{array}{c}{ }^{60} \mathrm{Co} \\
(\mathrm{pC} \mathrm{i} / \mathrm{mL})\end{array}$ & 筒/ $0_{3}^{-}$ & $\begin{array}{c}u \\
\text { (mg/L) }\end{array}$ \\
\hline \multicolumn{2}{|c|}{ Table II Limits } & $N A^{a}$ & $\mathrm{NA}^{a}$ & $3.00 E+03$ & $3.00 E-01$ & $2.00 \mathrm{E}+01$ & $1.00 E+01$ & $3.00 E+01$ & $4.5 E+01$ & \\
\hline $\begin{array}{l}\text { 2E-33-26 } \\
\text { Maximumin } \\
\text { Mean } \\
\text { Minimum }\end{array}$ & $2|6-8-6|$ & & $5.63 \mathrm{E}-01^{b}$ & & & & & $1.50 \mathrm{E}-01^{b}$ & & \\
\hline $\begin{array}{l}2 E-33-27 \\
\text { Maximum } \\
\text { Mean } \\
\text { Minimum! }\end{array}$ & $216-B Y-T F$ & & $\begin{array}{l}3.80 E+00 \\
2.70 E+00 \\
1.80 E+00\end{array}$ & & & & & & & \\
\hline $\begin{array}{l}2 E-34-1 \\
\text { Maximun } \\
\text { Mean } \\
\text { Minimuin }\end{array}$ & & & $7.97 \mathrm{E}-02^{b}$ & $1.26 \mathrm{E}+00^{b}$ & & 7. $10 \mathrm{E}-02^{b}$ & & $2.00 \mathrm{E}-02^{b}$ & $5.93 \mathrm{E}-01^{b}$ & \\
\hline $\begin{array}{l}2 W-10-1 \\
\text { Maximum } \\
\text { Mean } \\
\text { Minimum }\end{array}$ & $216-\mathrm{T}-5$ & & $<6.10 \mathrm{E}-02^{b}$ & & & & & & & \\
\hline $\begin{array}{l}2 \mathrm{2K}-10-4 \\
\text { Maximum } \\
\text { Mean } \\
\text { Mininum }\end{array}$ & $216-T-36$ & & $\begin{array}{l}1.64 \mathrm{E}-01 \\
1.20 \mathrm{E}-01 \\
7.50 \mathrm{E}-02\end{array}$ & & & $.3 .17 E-03^{b}$ & & $6.62 \mathrm{E}-02^{b}$ & & \\
\hline $\begin{array}{l}2 W-10-8 \\
\text { Maximum } \\
\text { Mean } \\
\text { Mininun }\end{array}$ & 241-T-TF & & $1.70 \mathrm{E}-02^{b}$ & $9.50 \mathrm{E}-02^{b}$ & & & & $5.07 \mathrm{E}-02^{b}$ & & \\
\hline $\begin{array}{l}2 W-10-9 \\
\text { Maximum } \\
\text { Mean } \\
\text { Mintmum }\end{array}$ & $241-\mathrm{T}-\mathrm{TF}$ & $<1.70 \mathrm{E}-02^{b}$ & $\begin{array}{l}1.10 \mathrm{E}-01 \\
9.75 \mathrm{E}-02 \\
3.00 \mathrm{E}-02\end{array}$ & & & $<1.58 E-02$ & & $\begin{array}{r}4.70 \mathrm{E}-02 \\
3.12 \mathrm{E}-02 \\
<2.50 \mathrm{E}-02\end{array}$ & & \\
\hline $\begin{array}{l}2 W-11-11 \\
\text { Maximum } \\
\text { Mean } \\
\text { Minimum }\end{array}$ & $21 \overline{-}-T-18$ & & $\begin{array}{r}1.31 E-01 \\
9.10 E-02 \\
<7.50 E-02\end{array}$ & & & $6.88 \mathrm{E}-04^{b}$ & & $1.99 \mathrm{E}-02^{b}$ & & \\
\hline $\begin{array}{l}2 \mathrm{~W}-11-13 \\
\text { Maximum } \\
\text { Mean } \\
\text { Mininum }\end{array}$ & $200 \mathrm{w}$ & & $1.48 \mathrm{E}-01^{b}$ & $6.73 \mathrm{E}+01^{b}$ & & & & & $4.20 E+00$ & \\
\hline
\end{tabular}




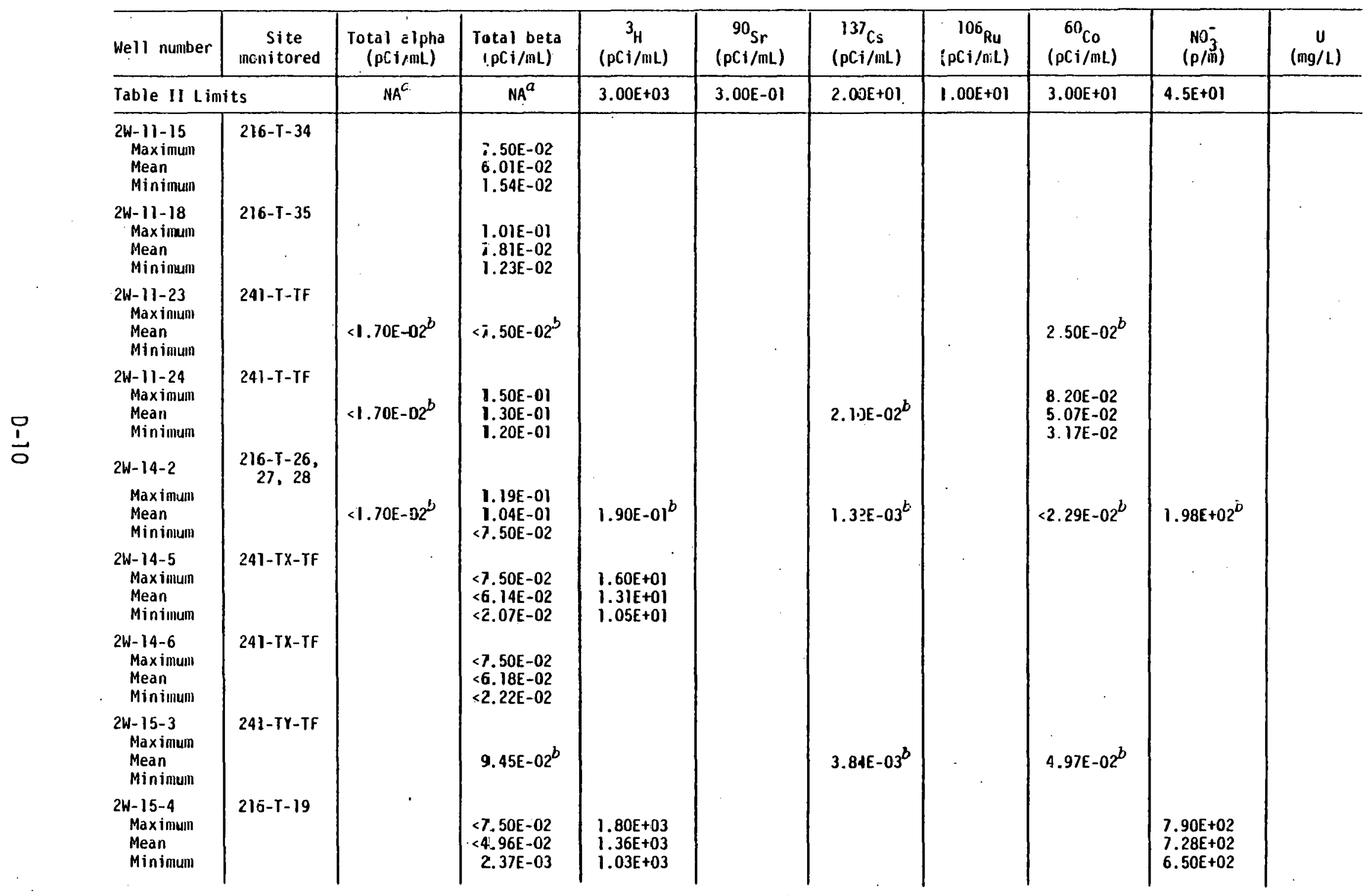




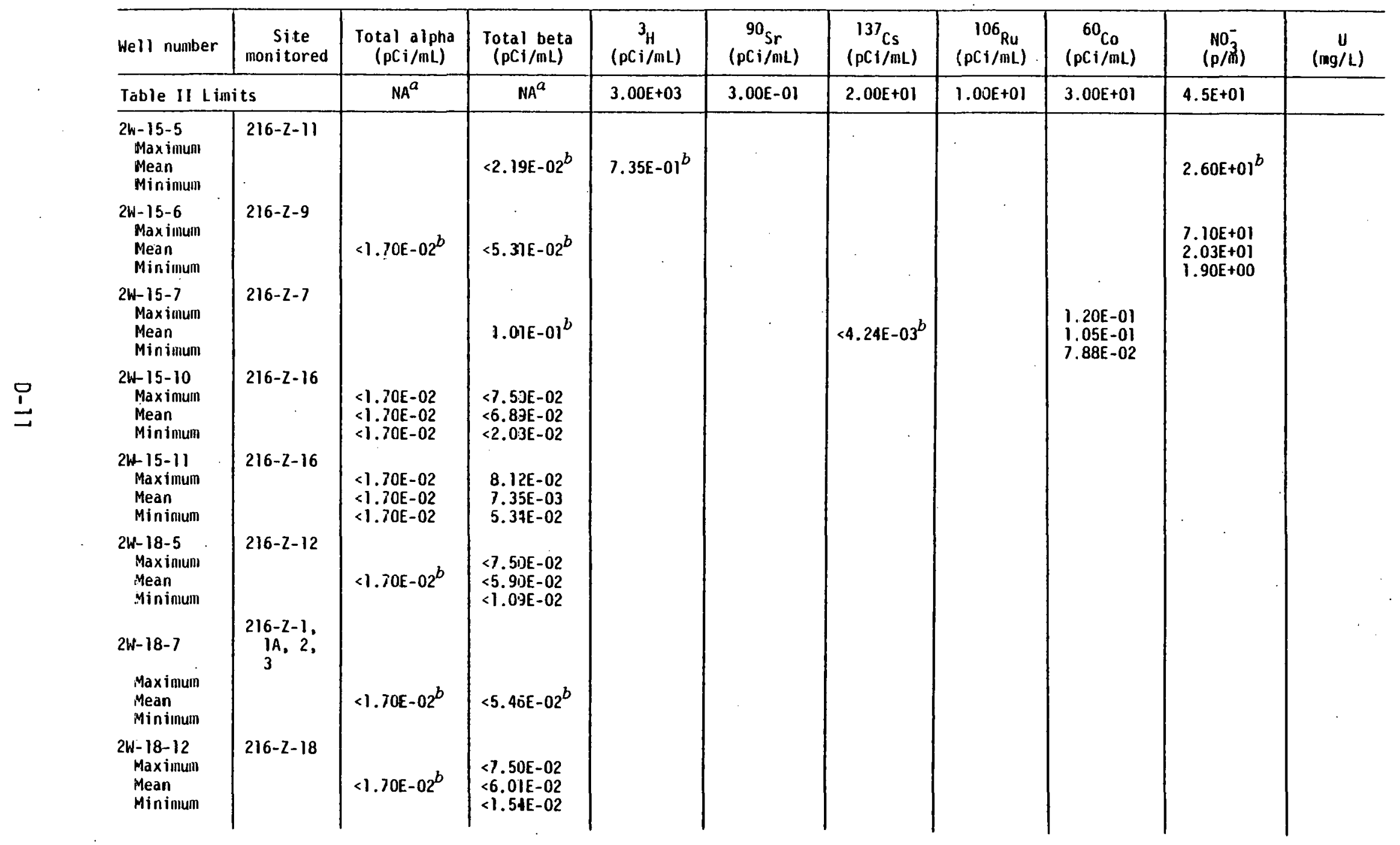




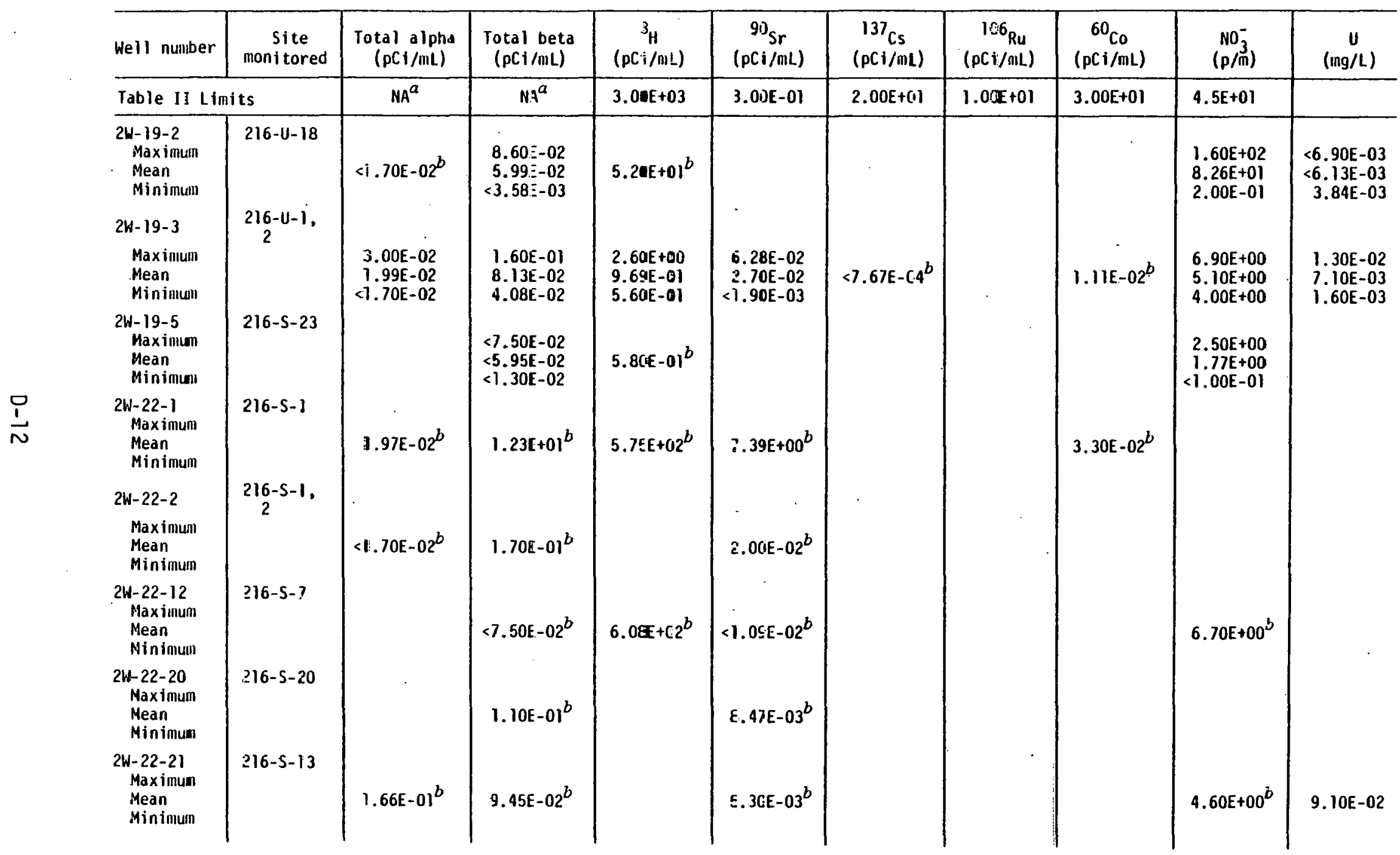




\begin{tabular}{|c|c|c|c|c|c|c|c|c|c|c|}
\hline Well number & $\begin{array}{c}\text { Site } \\
\text { morititored }\end{array}$ & $\begin{array}{l}\text { Total alpha } \\
\text { (pCi/mL) }\end{array}$ & $\begin{array}{l}\text { Tatal beta } \\
\text { (pCi/mL) }\end{array}$ & $\begin{array}{c}3_{\mathrm{H}} \\
(\mathrm{pCi} / \mathrm{mL})\end{array}$ & $\begin{array}{c}{ }^{90} \mathrm{Sr} \\
(\mathrm{pC} \mathrm{i} / \mathrm{mL})\end{array}$ & $\begin{array}{c}137 \mathrm{Cs} \\
(\mathrm{pC} / \mathrm{mL})\end{array}$ & $\begin{array}{c}106_{\mathrm{Ru}} \\
(\mathrm{pCi} / \mathrm{mL})\end{array}$ & $\begin{array}{c}{ }^{60} \mathrm{Co} \\
(\mathrm{pCi} j / \mathrm{mL})\end{array}$ & $\begin{array}{c}\mathrm{NO}_{3}^{-} \\
(\mathrm{p} / \mathrm{m})\end{array}$ & $\begin{array}{c}u \\
(m g / L)\end{array}$ \\
\hline \multicolumn{2}{|c|}{ Table II Limits } & $N A^{a}$ & $N A^{a}$ & $3.00 E+03$ & $3.00 E-01$ & $2.00 E+01$ & $1.00 E+01$ & $3.00 E+01$ & $4.5 E+01$ & \\
\hline $\begin{array}{c}2 W-22-22 \\
\text { Maximum } \\
\text { Mean } \\
\text { Minimum }\end{array}$ & $216-U-12$ & & $<7.50 \mathrm{E}-02^{b}$ & & & & & & & \\
\hline $\begin{array}{l}2 W-22-26 \\
\text { Maximum } \\
\text { Mean } \\
\text { Minimun }\end{array}$ & $216-5-9$ & & $<7.50 \mathrm{E}-02^{b}$ & $5.65 \mathrm{E}+02^{b}$ & $3.95 \mathrm{E}-03^{b}$ & & & & & \\
\hline $\begin{array}{l}2 \mathrm{~W}-22-27 \\
\text { Maximum } \\
\text { Mean } \\
\text { Minimum }\end{array}$ & $216-5-9$ & & $<1.73 E-02^{b}$ & $9.35 E+00^{b}$ & & & & & $3.80 E+00^{b}$ & \\
\hline $\begin{array}{l}2 W-23-1 \\
\text { Maximum } \\
\text { Mean } \\
\text { Minimum }\end{array}$ & $216-5-3$ & & $<7.50 \mathrm{E}-02^{b}$ & & & & & & & \\
\hline $\begin{array}{l}\text { chW-23-2 } \\
\text { Maximum } \\
\text { Mean } \\
\text { Minimum }\end{array}$ & $241-5 x-T F$ & & $7.65 \mathrm{E}-02^{b}$ & & & & & & & \\
\hline $\begin{array}{l}\text { 2W-23-3 } \\
\text { Maxiinum } \\
\text { Mean } \\
\text { Minimum }\end{array}$ & $241-5 X-T F$ & & $<7,50 \mathrm{E}-02^{b}$ & & & & & & & \\
\hline $\begin{array}{l}2 \text { 'N-23-4 } \\
\text { Maximum } \\
\text { Mean } \\
\text { Minimum }\end{array}$ & $216-5-21$ & 3. $37 \mathrm{E}-02^{b}$ & $<7.50 \mathrm{E}-02^{b}$ & $3.03 \mathrm{E}+00^{b}$ & & & & & $5.67 \mathrm{E}-01^{b}$ & $2.10 \mathrm{E}-02$ \\
\hline $\begin{array}{l}2 \mathrm{H}-23-9 \\
\text { Maximum } \\
\text { Mean } \\
\text { Minimum }\end{array}$ & $216-\leq-25$ & $2.07 \mathrm{E}-02^{b}$ & $\begin{array}{r}<7.5 .0 E-02 \\
<6.6 .3 E-02 \\
1.46 E-02\end{array}$ & $\begin{array}{l}2.70 E+03 \\
4.65 E+02 \\
1.20 E+02\end{array}$ & & $<2.61 \mathrm{E}-03^{b}$ & & $<1.81 E-02^{b}$ & & \\
\hline $\begin{array}{l}\text { 2W-23-10 } \\
\text { Maximuln } \\
\text { Mean } \\
\text { Minimum }\end{array}$ & $216-5-25$ & & $\begin{array}{r}<7.50 \mathrm{E}-02 \\
<6.85 \mathrm{E}-02 \\
1.62 \mathrm{E}-02\end{array}$ & $\begin{array}{l}3.10 E+03 \\
1.02 E+03 \\
9.90 E-01\end{array}$ & $4.97 E-03^{b}$ & $2.50 E-04^{b}$ & & $7.14 \mathrm{E}-03^{b}$ & & \\
\hline
\end{tabular}




\begin{tabular}{|c|c|c|c|c|c|c|c|c|c|c|}
\hline Hell number & $\begin{array}{c}\text { Site } \\
\text { monitored }\end{array}$ & $\begin{array}{l}\text { Total alpsa } \\
\text { (pCi/mL: }\end{array}$ & $\begin{array}{c}\text { Total beta } \\
(p C i / m L)\end{array}$ & $\begin{array}{c}3_{H} \\
(p \in i / m L)\end{array}$ & $\begin{array}{c}90 \mathrm{Sr} \\
(\mathrm{pCi} / \mathrm{mL})\end{array}$ & $\begin{array}{c}{ }^{137} \mathrm{Cs} \\
(\mathrm{pCi} / \mathrm{mL})\end{array}$ & $\begin{array}{c}10.6_{R u} \\
\text { (pCi/mL) }\end{array}$ & $\begin{array}{c}60 c_{0} \\
(p C i / m L)\end{array}$ & $\begin{array}{l}\mathrm{NO}_{3}^{-} \\
(\mathrm{p} / \mathrm{m})\end{array}$ & $\underset{(m g / L)}{U}$ \\
\hline \multicolumn{2}{|c|}{ Table II Limits } & $N A^{a}$ & $\mathrm{NA}^{a}$ & $3.00 E+03$ & 3.100E-01 & $2.00 E+01$ & $1.00 \mathrm{E}+0.1$ & $3.00 E+01$ & $4.5 E+01$ & \\
\hline $\begin{array}{l}2 \mathrm{~W}-26-3 \\
\text { Maxinum } \\
\text { Mean } \\
\text { Minimum }\end{array}$ & $216-5-6$ & $=1.70 \mathrm{E}-02^{D}$ & $7.50 \mathrm{E}-02^{b}$ & $<5.83 \mathbf{E}-01^{\grave{D}}$ & & & & & $6.30 \mathrm{E}-01^{b}$ & \\
\hline $\begin{array}{l}\text { 699-32-72 } \\
\text { Maximum } \\
\text { Mean } \\
\text { Minimum }\end{array}$ & $216-5-19$ & & $=3.07 \mathrm{E}-03^{b}$ & $\begin{array}{l}\text { 1. } 50 E+02 \\
1.36 E+02 \\
1.20 E+02\end{array}$ & & & & & $\begin{array}{r}3.30 E+00 \\
1.20 E+00 \\
<5.00 E-01\end{array}$ & \\
\hline $\begin{array}{l}\text { 699-35-78 } \\
\text { Maximum } \\
\text { Mean } \\
\text { Mininum }\end{array}$ & $216-11-10$ & & $\begin{array}{l}=7.50 \mathrm{E}-02 \\
=6.00 \mathrm{E}-02 \\
=9.47 \mathrm{E}-03\end{array}$ & $\begin{array}{l}<B .0 C E-01 \\
<6 . \text { ICE-01 } \\
3 . I C E-01\end{array}$ & & & & & $\begin{array}{r}7.00 E-01 \\
5.85 E-01 \\
<5.00 E-01\end{array}$ & \\
\hline $\begin{array}{c}\text { 699-53-47 } \\
\text { Maximum } \\
\text { Mean } \\
\text { Minimum }\end{array}$ & $216-A-25$ & & $<3.75 E-02^{b}$ & $\begin{array}{r}\text { 1. } 3 \text { 3EE } 00 \\
\text { 7. } 5 \mathrm{~B}-01 \\
<4 . \text { ICE-01 }\end{array}$ & & & . & & $\begin{array}{l}<5.00 \mathrm{E}-01 \\
<5.00 \mathrm{E}-01 \\
<5.00 \mathrm{E}-01\end{array}$ & \\
\hline $\begin{array}{l}\text { 699-53-55A } \\
\text { MaximumI } \\
\text { Mean } \\
\text { MinimumI }\end{array}$ & $216-A-25$ & $<3.75 \mathrm{E}-02^{\mathrm{J}}$ & $\begin{array}{l}<9.00 E-01 \\
<6.30 E-01 \\
<5.00 E-01\end{array}$ & & & & & & $\begin{array}{l}<5.00 \mathrm{E}-01 \\
<5.00 \mathrm{E}-01 \\
<5.00 \mathrm{E}-01\end{array}$ & \\
\hline
\end{tabular}

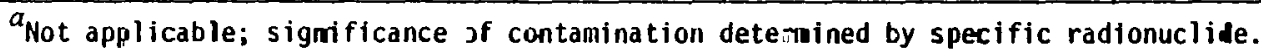

${ }^{b}$ Three values or less, no maxinum or minimum calculated. 


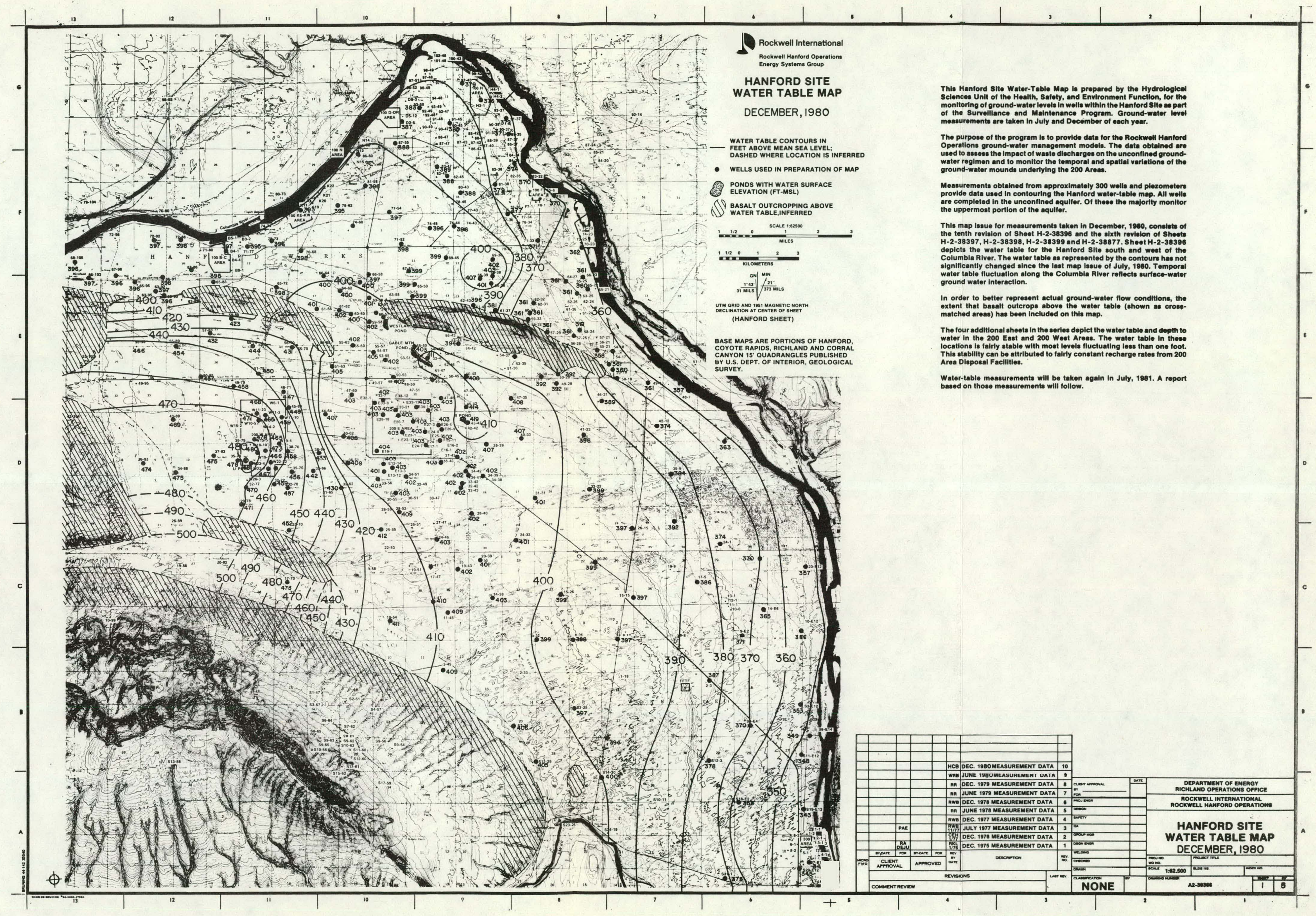


DISTRIBUTION

Number of copies

OFFSITE

2

Technical Information Center

P.0. Box 62

Oak Ridge, Tennessee 37830

2

United States Testing Company George Washington Way

Richland, Washington 99352

W. V. Baumgartner

M. M. Lardy

ONSITE

3

Pacific Northwest Laboratory.

P. E. Eddy

V. L. McGhan

D. A. Myers

4

U.S. Department of Energy

Richland Operations Office

Richland, Washington 99352

E. A. Bracken

R. E. Gerton

J. L. Rhoades

J. J. Schreiber

85

Rockwell Hanford Operations

B. N. Anderson

H. C. Baze

G. F. Boothe

W. R. Brown (2)

M. A. Christie

D. E. Conover

F. A. Deluca

D. W. Duncan

K. R. Fecht

R. E. Gephart

M. J. Graham (5)

M. D. Hall

V. W. Hall

W. M. Hayward

W. F. Heine (2)

W. A. Jordan

R. B. Kasper 
Rockwell Hanford Operations (Continued)

G. V. Last

A. G. Law

L. S. Leonhart

W. M. Lindsay

P. G. Lorenzini

A. H. Lu

H. E. McGuire

W. B. Mc Intyre

T. J. McLaughl in

R. M. Mitchell

B. A. Moore

D. A. Parks

S. M. Price

W. H. Price (2)

R. C. Routson

J. B. Sisson

R. M. Smith

F. A. Spane

D. L. Uhl

G. L. Wagenaar

R. E. Wheeler

S. A. Wiegman

T. J. Wood

EA\&M Library (30)

BWIP Library (2)

Dor.ument. Control (2)

Report Coordination and

Production (4) 